\title{
The International Soil Moisture Network: a data hosting facility for global in situ soil moisture measurements
}

\author{
W. A. Dorigo ${ }^{1}$, W. Wagner ${ }^{1}$, R. Hohensinn ${ }^{1}$, S. Hahn ${ }^{1}$, C. Paulik ${ }^{1}$, A. Xaver ${ }^{1}$, A. Gruber ${ }^{1}$, M. Drusch ${ }^{2}$, \\ S. Mecklenburg ${ }^{3}$, P. van Oevelen ${ }^{4}$, A. Robock ${ }^{5}$, and T. Jackson ${ }^{6}$ \\ ${ }^{1}$ Institute of Photogrammetry and Remote Sensing (IPF), Vienna University of Technology, Vienna, Austria \\ ${ }^{2}$ European Space Agency, ESTEC, Noordwijk, The Netherlands \\ ${ }^{3}$ European Space Agency, ESRIN, Frascati, Italy \\ ${ }^{4}$ International GEWEX Project Office (IGPO), Silver Spring, Maryland, USA \\ ${ }^{5}$ Department of Environmental Sciences, Rutgers University, New Brunswick, New Jersey, USA \\ ${ }^{6}$ Hydrology and Remote Sensing Laboratory, Agricultural Research Service, US Department of Agriculture, Beltsville, USA
}

Received: 20 January 2011 - Published in Hydrol. Earth Syst. Sci. Discuss.: 3 February 2011

Revised: 23 May 2011 - Accepted: 24 May 2011 - Published: 30 May 2011

\begin{abstract}
In situ measurements of soil moisture are invaluable for calibrating and validating land surface models and satellite-based soil moisture retrievals. In addition, longterm time series of in situ soil moisture measurements themselves can reveal trends in the water cycle related to climate or land cover change. Nevertheless, on a worldwide basis the number of meteorological networks and stations measuring soil moisture, in particular on a continuous basis, is still limited and the data they provide lack standardization of technique and protocol. To overcome many of these limitations, the International Soil Moisture Network (ISMN; http://www.ipf.tuwien.ac.at/insitu) was initiated to serve as a centralized data hosting facility where globally available in situ soil moisture measurements from operational networks and validation campaigns are collected, harmonized, and made available to users. Data collecting networks share their soil moisture datasets with the ISMN on a voluntary and no-cost basis. Incoming soil moisture data are automatically transformed into common volumetric soil moisture units and checked for outliers and implausible values. Apart from soil water measurements from different depths, important metadata and meteorological variables (e.g., precipitation and soil temperature) are stored in the database. These will assist the user in correctly interpreting the soil moisture data. The database is queried through a graphical user interface while output of data selected for download is provided according to common standards for data and metadata.
\end{abstract}

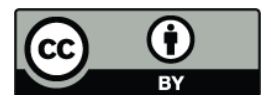

Correspondence to: W. A. Dorigo (wd@ipf.tuwien.ac.at)
Currently (status May 2011), the ISMN contains data of 19 networks and more than 500 stations located in North America, Europe, Asia, and Australia. The time period spanned by the entire database runs from 1952 until the present, although most datasets have originated during the last decade. The database is rapidly expanding, which means that both the number of stations and the time period covered by the existing stations are still growing. Hence, it will become an increasingly important resource for validating and improving satellite-derived soil moisture products and studying climate related trends. As the ISMN is animated by the scientific community itself, we invite potential networks to enrich the collection by sharing their in situ soil moisture data.

\section{Introduction}

Across many landscapes, soil moisture and its freeze/thaw state control evapotranspiration, thus providing the link between terrestrial and atmospheric water, energy, and carbon cycles (Robock et al., 2000). In addition, surface soil moisture is a determinant of the partitioning of surface precipitation into infiltration and runoff. The availability of better spatial estimates of surface soil moisture conditions can therefore help to improve forecasting of precipitation, droughts and floods as well as climate projections and predictions (Dirmeyer et al., 2006). It will also contribute to further the development of other hydrological applications that can support water managers and water resource decision-makers. The importance of soil moisture in the global climate system

Published by Copernicus Publications on behalf of the European Geosciences Union. 
has recently been underlined by the Global Climate Observing System (GCOS) by endorsing soil moisture as an Essential Climate Variable ${ }^{1}$.

The value of soil moisture for various applications is reflected by the large number of satellite-based soil moisture products that have emerged during the last decade. Only in 2000, Robock et al. (2000, p. 1298) concluded their paper stating: "There are no existing global soil moisture datasets measured from remote sensing". Today, a wide variety of operational global soil moisture products are available for existing microwave sensors such as AMSR-E (Jackson, 1993; Njoku et al., 2003; Koike et al., 2004; Owe et al., 2008), TRMM-TMI (Owe et al., 2008), SSM/I (Owe et al., 2008), WindSat (Li et al., 2010), ERS 1 and 2 (Wagner et al., 1999; Scipal et al., 2002), and ASCAT (Naeimi et al., 2009). In addition, special missions dedicated to soil moisture either have been recently launched, i.e. the Soil Moisture and Ocean Salinity Mission (SMOS) of the European Space Agency (ESA; Kerr et al., 2001; Wigneron et al., 2007), or are scheduled for the near future, such as the Soil Moisture Active \& Passive (SMAP) mission of the United States National Aerospace Space Administration (NASA; Entekhabi et al., 2010a). In addition, global soil moisture products based on land surface models are being made available routinely through operational forecast systems, e.g. from the European Centre for Medium-Range Weather Forecasts (Drusch and Viterbo, 2007), re-analyses (Uppala et al., 2005; Simmons et al., 2007) or the soil moisture fields provided by the Global Land Surface Data Assimilation System (Rodell et al., 2004) and the Global Soil Wetness Project (Dirmeyer et al., 1999).

To calibrate and validate such satellite- and model-based soil moisture estimates, in situ measurements are an indispensable source of information (e.g. Ceballos et al., 2005; Wagner et al., 2007; Balsamo et al., 2009; Gruhier et al., 2010; Jackson et al., 2010; Liu et al., 2011). Moreover, in situ soil moisture measurements provide information that facilitates the study of the spatial and temporal variability of soil moisture at different scales (Famiglietti et al., 1999; Entin et al., 2000; Brocca et al., 2007), the exchange of water between different layers within the soil column or between the land surface and the atmosphere (Mahfouf and Noilhan, 1991; Chen and Hu, 2004; Albergel et al., 2008), and climate related trends in soil moisture (Robock et al., 2005).

Since the early 1980s, several dedicated soil moisture field campaigns in the US, Europe, and Australia have resulted in both short term and long term soil moisture datasets. Most of these campaigns were designed for satellite validation purposes. Of great historical importance were the soil moisture field experiments performed at the Beltsville Agricultural Research Center (BARC) where for one the first times remote sensing measurements were coupled with field observations (Wang et al., 1980). Being one of the first datasets publicly available, the BARC datasets triggered many researchers to

\footnotetext{
${ }^{1}$ http://gosic.org/ios/MATRICES/ECV/ECV-Introduction.htm
}

study the ability of retrieving soil moisture from space observations. Other historically important experiments include the Botswana experiment (Van De Griend et al., 1989), HAPEXSahel (Prince et al., 1995), EFEDA (Braud et al., 1993), FIFE (Peck and Hope, 1995), and the soil moisture experiments coordinated by the United States Department of Agriculture (e.g. Jackson et al., 2002).

The importance of soil moisture has been growing in importance also in the meteorological and hydrological communities and as a result several networks now measure soil moisture as a routine observation (e.g. Beyrich and Adam, 2007; Calvet et al., 2008) . Nevertheless, on a global basis the number of long-term in situ monitoring networks is still small and mostly restricted to mid-latitude regions. Only few measurements are being made in Africa and South America. Complicating the easy utilization of network data is the lack of a standard measurement technique and a standard measurement protocol (Robock et al., 2000). Also, the fact that the various datasets are managed by a large number of different organizations makes clear that global studies incorporating in situ soil moisture measurements are tedious to perform.

Actions to collect data from several networks and to offer a centralized portal for dissemination are basically confined to the historical Global Soil Moisture Data Bank previously existing at Rutgers University, NJ (Robock et al., 2000, 2005). This data archive provided data and metadata for various historical and operative networks around the globe. The dozens of scientific publications relying on its datasets have affirmed the importance of this dissemination platform. Although the Global Soil Moisture Data Bank was a good starting point for global validation efforts, the last update of the data base occurred in 2005 which made it unusable for the most recent and upcoming satellite-based soil moisture products listed above. In addition, the observations of the various networks in the Global Soil Moisture Data Bank were not harmonized in terms of measurement units. They were presented either as plant-available volumetric or as total volumetric soil moisture in $\mathrm{cm}$ or percent for a given soil layer depth. Hence, the soil water units needed to be carefully checked before performing a comparison.

The need for intensified international cooperation in establishing new monitoring networks and constructing centralized and harmonized global soil moisture datasets has been broadly recognized by the international community (Grabs and Thomas, 2002; Jackson et al., 2005). Hence, in 2006 the International Soil Moisture Working Group (ISMWG) was established to facilitate the creation of multi-source soil moisture datasets, including in situ observations. The development of these datasets and an in situ soil moisture network was consequently included in the Group on Earth Observation (GEO) 2009-2011 Work Plan under sub-task WA08-01a lead by the Global Energy and Water Cycle Experiment (GEWEX) and ESA. Its implementation is coordinated through the ISMWG under auspices of GEWEX. The 
launch of SMOS in November 2009 has given a strong impulse to the establishment of a centralized data hosting facility for in situ soil moisture measurements in support of a reliable calibration and validation of the mission soil moisture products. It was recognized that an integrated system was needed to host quality-controlled and harmonized soil moisture measurements from the various worldwide ground validation campaigns and networks. For this reason, ESA has supported the development and first phase of operation of a data hosting facility called the International Soil Moisture Network (Dorigo et al., 2011). The International Soil Moisture Network (ISMN) has been implemented by the Vienna University of Technology and provides no-cost access to its datasets for all users.

This article gives an overview of the ISMN, which can be accessed through http://www.ipf.tuwien.ac.at/insitu. To put the structure of the system and the data manipulations performed within the system into a clearer context, the article starts with an overview of soil moisture definitions and the measurement techniques and instruments commonly used to measure soil moisture in situ (Sect. 2). Section 3 provides an overview of the technical design and implementation of the ISMN, and the methods used for harmonizing the soil moisture datasets. Section 4 summarizes the datasets currently contained in the database. Even though the number of networks and stations are still rapidly increasing (visit http: //www.ipf.tuwien.ac.at/insitu/index.php/news.html for news on recent updates), this section intends to provide insight in the diversity of the datasets that are considered for integration in the ISMN. Section 5 discusses the possible outreach of the ISMN and some issues that should be taken into consideration if in situ soil moisture data are used for calibration and validation of remote sensing products and land surface models. Section 6 concludes this paper by looking into the future and outlining some prerequisites for a successful continuation of the ISMN.

\section{Measuring in situ soil moisture}

\subsection{Soil moisture definitions and units}

Soil moisture $(\Theta)$ is usually defined as the water present in the unsaturated part of the soil profile, i.e., between the soil surface and the ground water level and can be expressed in different units (e.g. Fredlund and Rahardjo, 1993; Hillel, 1998; Robock et al., 2000; Seneviratne et al., 2010). An understanding of the different definitions is crucial for homogenization of the soil moisture measurements. The most common definition of soil moisture is volumetric soil moisture. It is either expressed as the volumetric fraction of water in a given soil depth $\left[\mathrm{m}^{3}\right.$ water per $\mathrm{m}^{3}$ soil] or as the depth of a column of water contained in a given depth of soil [mm water per $\mathrm{mm}$ soil]. The volumetric fraction $\left[\mathrm{m}^{3} \mathrm{~m}^{-3}\right]$ is most widespread in earth observation. Therefore, this is also the unit adopted in the ISMN. Datasets that are provided in other units will be converted to this unit (Sect. 3.3.2). Some other relevant descriptors are presented below.

Soil moisture can also be expressed as fraction of saturation. A fraction of the soil, typically less than 0.5 , consists of pores that can be filled with air or water. This fraction is called the porosity $(P)$. If this fraction were completely filled with water, the soil would reach its maximum soil moisture content or saturation. The saturation ratio varies between 0 (no soil moisture) and 1 (full saturation). The porosity, or water storage capacity, is needed to convert the saturation ratio into volumetric fraction.

Another commonly used term is plant available water (PAW), which is the volume of water available to plants. PAW is computed by subtracting the volume of water corresponding to the permanent wilting point from the total volumetric soil water content. Below the wilting point water is held too strongly by the soil matrix and is not accessible to plants (Hillel, 1998). The wilting point depends on soil properties such as soil texture, and thus varies geographically.

Essential for the definition of soil moisture is the characterization of the soil volume, as soil moisture content is not homogeneously distributed vertically and horizontally and thus depends on the soil volume considered. This is of high relevance for intercomparing in situ measurements originating from different stations and for the comparison of in situ measurements with Earth observation and land surface model data. For example, some methods sample only soil moisture in the top few millimeters to centimeters of the soil (e.g., microwave remote sensing), a small volume at a given depth (e.g., Time Domain Reflectometry (TDR) measurements Sect. 2.2), or provide an integral measure down to the water table depth. Moreover, for certain soil moisture definitions (e.g., root zone soil moisture, total soil moisture), $\Theta$ may be a function of space and time (i.e., as a function of the plants' rooting depth or the water table depth).

For a more extensive description of soil moisture definitions we refer the reader to existing literature (e.g. Hillel, 1998; Seneviratne et al., 2010).

\subsection{Measurement techniques}

Several techniques are available for measuring soil moisture content in situ (Ward and Robinson, 1990; Robock et al., 2000; Walker et al., 2004; Robinson et al., 2008; Seneviratne et al., 2010). They can be categorized either as direct or indirect methods. The most frequently used methods are summarized below. For a more detailed discussion we refer to the references cited above.

\subsubsection{Gravimetric method}

The gravimetric method is the only method that measures soil moisture directly. Typically, soil samples are taken using coring devices or augers at specific depths and locations. The 
samples are weighted before and after drying, and from the changes in mass, the soil moisture content can be derived. The method is labor-intensive and destructive (i.e., a sample cannot be taken at exactly the same location more than once). When implemented as a monitoring technique, the temporal resolution of long-term measurement networks using this technique is usually coarse, typically of the order of 1-2 weeks at best (Seneviratne et al., 2010). Nevertheless, as the gravimetric method is low-tech and simple, it makes an excellent technique for long homogeneous climatological records (Robock et al., 2000). Today, most systematic observations are based on indirect methods; however, calibration typically requires using the gravimetric method.

\subsubsection{Neutron probes}

Neutron probes are relatively easy to use, accurate, and capable of measurements in real time. This indirect method uses a radioactive source of fast (high-energy) neutrons, which is lowered into a borehole, and the backscattered slow neutrons are measured. A detector counts the number of neutrons slowed down or thermalized by collisions with hydrogen nuclei, mainly representing soil water. A relationship with volumetric soil moisture content is obtained by calibrating the slow neutron counts with gravimetric samples of soil moisture content and bulk densities (Vachaud et al., 1977). Since radioactive scattering occurs over a spherical domain, a neutron probe samples a volume of soil rather than a point. The probe's relatively large volume of influence makes observations at shallow depths prone to errors, as adjoining air is also sampled. Disadvantages of neutron probes include their requirement to be calibrated to soil types and zones over a period of time with different soil moisture fractions, that they are also labor-intensive, the need for precautions associated with handling radioactive material, and the relatively high costs. It is also not adaptable to frequent and automated observations. The neutron probe is mostly used to measure soil moisture differences rather than absolute soil moisture content.

\subsubsection{Electromagnetic techniques}

Soil capacitance measurements, TDR, and Frequency Domain Reflectometry (FDR) are electromagnetic techniques that make use of the dependency of the dielectric permittivity of the soil on soil moisture content, caused by the difference between the dielectric constant of soil components and water, respectively. These techniques are non-destructive and non-radioactive and can be easily set up for automated operation with a data logger. This facilitates frequent measurements up to several measurements per hour. TDR and FDR sensors, operating at higher frequencies, are more accurate than capacitance sensors (e.g. Robinson et al., 2008). However, the latter are of much lower cost, which can allow for a higher number of instruments and thus much denser net- works (e.g., Bogena et al., 2007). On the other hand, FDR is sensitive to temperature fluctuations and ideally would need to be corrected for these. All techniques require calibration with gravimetric samples.

\subsubsection{Cosmic-ray neutrons}

Recently, a non-invasive method has been proposed that measures low-energy cosmic-ray neutrons that are generated within the soil, moderated mainly by hydrogen atoms, and diffused back to the atmosphere (Zreda et al., 2008; Desilets et al., 2010). These neutrons are sensitive to water content changes, but largely insensitive to variations in soil chemistry. Their intensity above the surface is inversely correlated with hydrogen content of the soil. Portable neutron detectors are placed a few meters above the ground and allow for a sampling interval of several minutes to hours. Soil moisture information is inferred over a depth of 15 to $70 \mathrm{~cm}$. In contrast to the methods presented above, cosmic-ray measurements integrate soil moisture measurements over much larger horizontal scales (diameter $\sim 670 \mathrm{~m}$ ) and hence have the potential to bridge the spatial mismatch between point measurements using contact methods and remote sensing estimates over large areas. Several operational and experimental networks based on this method are currently set-up worldwide $^{2}$.

\subsubsection{Other indirect techniques}

Tensiometers and electrical resistance blocks are capable of measuring the matric potential of soil water, which is directly related to the ability of plants to extract water from soil. However, each instrument has a limited accessible water potential range. Tensiometers work well only in wet soils, whereas resistance blocks (mostly made of gypsum) do better in moderately dry soils (WMO8, 2008). Keeping in mind these known limitations they are sufficiently reliable and inexpensive. However, tensiometers are relatively service intensive and sensitive to temperature fluctuations while resistance blocks need careful (re-)calibration during longer operation periods. Both sensor types are frequently used for agricultural purposes. A detailed description of these methods can be found in (WMO8, 2008).

Heat dissipation (or pulse) sensors measure temperature changes in response to a heat pulse (Robock et al., 2000). It makes use of the principle that the thermal behavior of the soil is closely related to its water content. Other indirect soil moisture measurement techniques include gamma densitometry (based on the relatively greater gamma radiation attenuation factor of water compared to other soil components) and psychrometers. All these indirect techniques need to be recalibrated with gravimetric samples.

\footnotetext{
${ }^{2}$ COSMOS:http://cosmos.hwr.arizona.edu/
} 
Table 1. Static station parameters contained in the ISMN that are either mandatory $(\mathrm{M})$, conditional $(\mathrm{C})$ or optional $(\mathrm{O})$ for a correct interpretation of in situ soil moisture measurements. A conditional input is only required when soil moisture is provided in units or definitions other than fractional volumetric soil moisture in $\mathrm{m}^{3} \mathrm{~m}^{-3}$ and the respective information is needed to convert it to the latter.

\begin{tabular}{lll}
\hline Variable name & Unit & \\
\hline Location & degree lat/lon (Range: & $\mathrm{M}$ \\
& $[-90,90],[-180,180])$ & \\
Elevation & $\mathrm{m}$ & $\mathrm{M}$ \\
Slope & degree & $\mathrm{O}$ \\
Aspect & degree & $\mathrm{O}$ \\
Land cover & descriptive & $\mathrm{O}$ \\
Land use & descriptive & $\mathrm{O}$ \\
Photo & - & $\mathrm{O}$ \\
Soil salinity & $\mathrm{dS} \mathrm{m} \mathrm{m}^{-1}$ & $\mathrm{O}$ \\
Soil bulk density & $\mathrm{kg} \mathrm{m} \mathrm{m}^{-3}$ & $\mathrm{C}$ \\
Soil porosity & $\%\left(\mathrm{~m}^{3} \mathrm{~m}^{-3} \times 100\right)$ & $\mathrm{C}$ \\
Soil texture & $\%$ clay, silt, sand & $\mathrm{C}$ \\
Soil textural class & $\mathrm{Descriptive}^{-}$different systems & $\mathrm{C}$ \\
Soil depth & $\mathrm{cm}^{3}$ & $\mathrm{O}$ \\
Residual water content & $\mathrm{m}^{3} \mathrm{~m}^{-3}$ & $\mathrm{C}$ \\
Saturation water content & $\mathrm{m}^{3} \mathrm{~m}^{-3}$ & $\mathrm{C}$ \\
Wilting point & $\%\left(\mathrm{~m}^{3} \mathrm{~m}^{-3} \times 100\right)$ & $\mathrm{C}$ \\
Field capacity & $\%\left(\mathrm{~m}^{3} \mathrm{~m}^{-3} \times 100\right)$ & $\mathrm{C}$ \\
\hline
\end{tabular}

\section{Implementation of the ISMN data hosting facility}

\subsection{Data and metadata included}

The ultimate goal of the ISMN is to provide a system for the dissemination of quality-controlled and harmonized soil moisture measurements from various ground validation campaigns and operational networks. Harmonization and quality control of soil moisture datasets can only be performed if sufficient data and metadata are available (Sects. 3.3 and 3.4). The information that is useful in interpreting the soil moisture measurements can be subdivided into information that is considered either static (site characteristics) or that is highly variable over time (e.g. most meteorological and hydrological variables).

The static variables that are included in the ISMN are summarized in Table 1. The coordinates of the measurement stations are obligatory. Conditional variables like bulk density and soil porosity are needed if soil moisture data are provided in units other than volumetric soil moisture and, as a consequence, the data need to be converted (Sect. 3.3.2). All other variables are not obligatory, but are very useful for a qualitative interpretation of observed soil moisture dynamics or encountered anomalies, e.g., between satellite-derived soil moisture and soil moisture contents measured in situ. Even though the variables listed in Table 1 may be considered static over time, they usually vary with depth.
Table 2. Meteorological and hydrological variables useful for the interpretation of soil 1 moisture data.

\begin{tabular}{|c|c|c|}
\hline Quantity name & Unit & Measuring device typically used \\
\hline Precipitation & $\mathrm{mm} \mathrm{h}^{-1}$ & $\begin{array}{l}\text { Storage-type gage or } \\
\text { tipping bucket }\end{array}$ \\
\hline Air temperature at $2 \mathrm{~m}$ & ${ }^{\circ} \mathrm{C}$ & Thermistor, thermometer \\
\hline Soil temperature & ${ }^{\circ} \mathrm{C}$ & Thermistor, thermometer \\
\hline Soil suction & $\mathrm{kPa}$ & Psychrometer \\
\hline Snow water content & $\%$ & $\begin{array}{l}\text { Snow pillow device and a } \\
\text { pressure transducer }\end{array}$ \\
\hline Snow depth & $\mathrm{cm}$ & Sonic sensor \\
\hline Ground water level & $\mathrm{cm}$ & Pressure sensor \\
\hline
\end{tabular}

Table 2 summarizes the meteorological and soil variables that vary over time that can be optionally included in the ISMN. Not all variables are measured at all stations. Some of the variables (e.g., soil suction) are directly related to the soil moisture content, whereas others (e.g., soil temperature and precipitation) can be helpful indicators of soil moisture data quality (Sect. 3.4). Temporal sampling resolutions of these variables (including soil moisture measurements) vary from $10 \mathrm{~min}$ to infrequent measurements every couple of days or even weeks, although an hourly sampling interval is most common. The sampling rate of the original soil moisture measurements for each network will be summarized in Sect. 4.

\subsection{System overview}

\subsubsection{General layout}

The data hosting facility has been designed fulfilling the following requirements: Firstly, the data hosting facility had to be able to store all relevant information for the networks, the stations, the datasets, and the measurements techniques. Secondly, this information should also be easily accessible, e.g., by users who are looking for datasets within a specific region of interest, or by users that for satellite product validation are interested only in soil moisture measurements of the top soil layer. Finally, any modifications made to the original data, like harmonization, should be traceable and the user should be able to invert this procedure to obtain the original measurement values (e.g., plant available water).

Based on these considerations the following system was implemented (Fig. 1):

1. software for automated reading, conversion, harmonization, and quality checking of input data,

2. a database containing the harmonized data and metadata, and

3. a web portal to provide the interface between the database and user queries and output. 


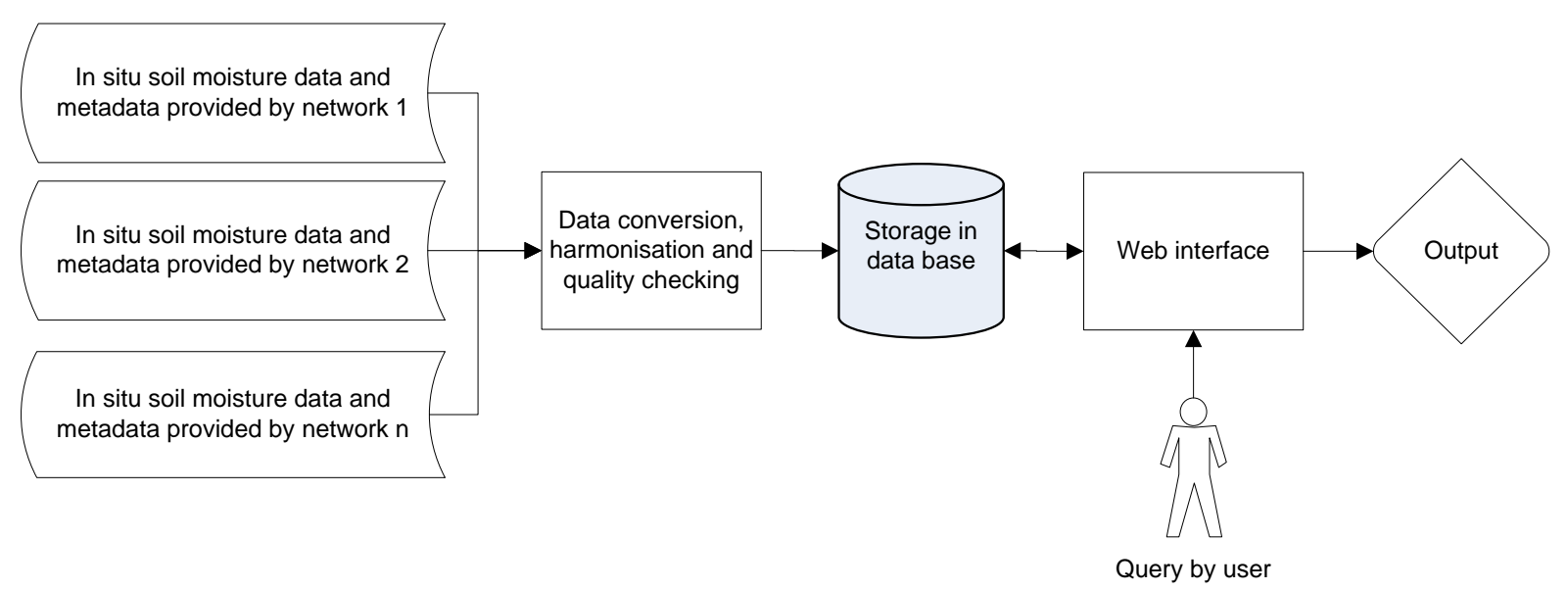

Fig. 1. Conceptual overview of ISMN.

The last two items are presented in this section, whereas data harmonization and quality control are discussed in Sects. 3.3 and 3.4, respectively.

The system is automated to the highest degree possible to facilitate the processing of large datasets and frequent updates. In practice, this means that data harmonization, quality control, and archiving are performed in a fully automated way. Only the ingestion into the system of the original datasets needs to be tailored to the specific network, as the data made available to the ISMN (e.g., by email or by download) are very heterogeneous with respect to file naming, file type, file format, the variables measured, and the metadata available. All data manipulations are performed in the Interactive Data Language (IDL) of ITT-VIS ${ }^{3}$.

\subsubsection{Database}

The database (or archive) is the core of the ISMN data hosting facility. Its design was very critical, since inadequate design considerations can significantly slow down operation when the database gets filled or leads to a database structure that is incapable of assimilating new networks with a different design or measurement setup. The design and content of the database was established after inventorying potential contributing networks, expected soil moisture and other datasets, possible users, and standards for hydrometeorological and spatial data and metadata (Sect. 3.2.4). Thus, an overview of expected database entries, data volumes, and data traffic could be established. A prototype of the data hosting facility was first tested with a selected number of users and data providers and, wherever feasible, modified to their suggestions.

The database distinguishes between mandatory, conditional, and optional database entries (see also Tables 1-2) and uses the following hierarchy: network $>$ station $>$ dataset.

\footnotetext{
${ }^{3}$ http://www.ittvis.com
}

Apart from data and metadata of soil moisture and other variables, additional relevant information on the networks and the stations is included, e.g., the responsible organization or references to more detailed information on the networks and sites. Among others, an important design consideration has been the use of a measurement depth interval ("from - to") to comply with the different measurement techniques and installation positions of the sensors. In the case of a variable measured at a specific depth, the "from" and "to" depths are identical.

The database was implemented in the open-source objectrelational database management system PostgreSQL ${ }^{4}$ (version 8.4) including the spatial database extension PostGIS ${ }^{5}$ 1.3.6.

\subsubsection{Web portal}

The ISMN can be accessed at http://www.ipf.tuwien.ac.at/ insitu. It consists of two major parts: (i) a project website providing details about networks, partners, and the project itself, and (ii) the data hosting centre itself where users can query, view, and download the data contained in the database.

Figure 2 shows a screenshot of the initial view of the data hosting centre. It embeds a Google Maps application programming interface (API), which offers the user a map-based selection tool to view and download the available data. In addition, through the satellite data and orthophotos in Google Maps the user is able to obtain additional information about the land use/land cover and topography in the vicinity of the measurement stations. By clicking on the markers, the user obtains a summary of important metadata about the networks or stations, respectively, depending on the zoom level within Google Maps. For a selected station the available data can be viewed in a data viewer to get a first impression of the

\footnotetext{
${ }^{4}$ http://www.postgresql.org/

${ }^{5} \mathrm{http}: / /$ postgis.refractions.net/
} 


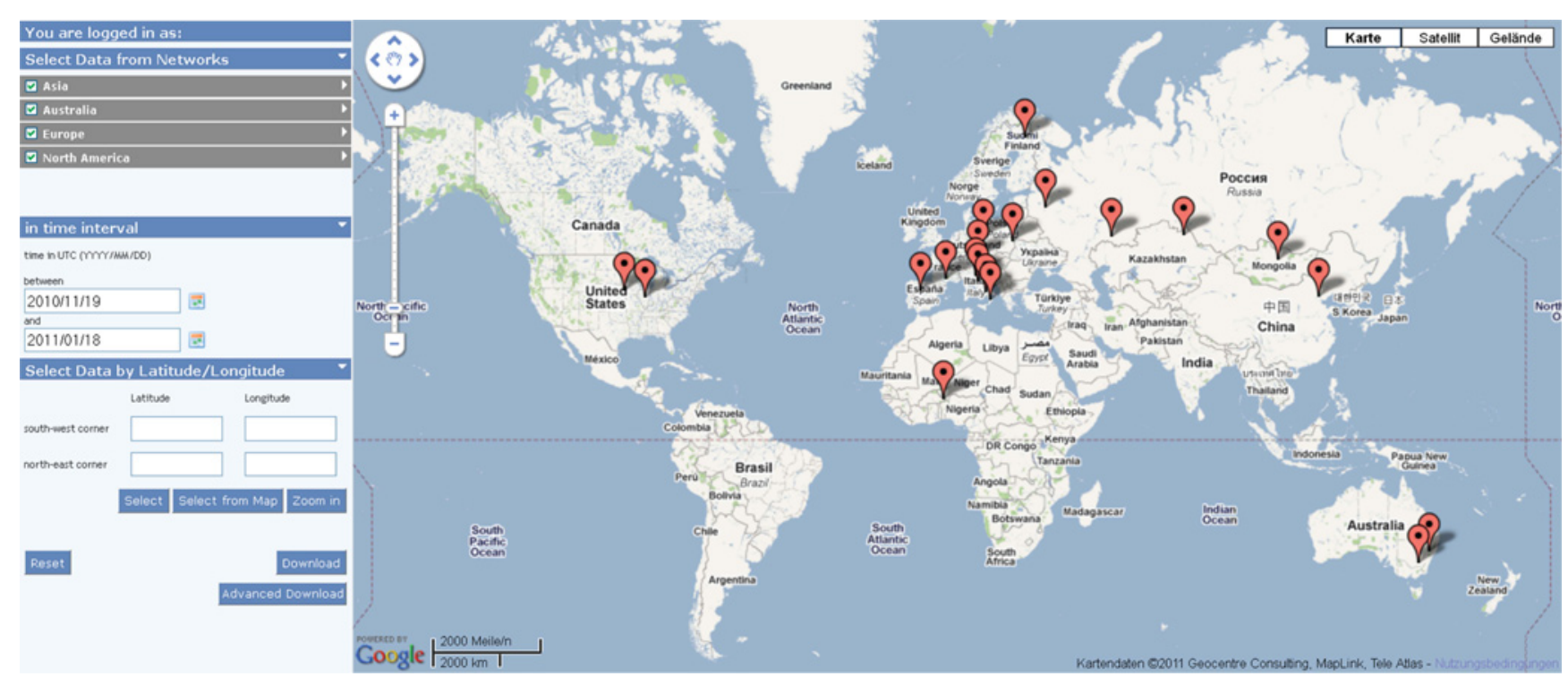

Fig. 2. Web interface of ISMN. Red droplets indicate the center coordinates of the different networks contained in the database (Status as of May 2011).

availability and quality of the data (Fig. 3). Apart from the map-based selection, the graphical data selection can also be refined by selecting continent, network, latitude/longitude, and time period. Finally, an advanced download window offers the possibility to make any query in the database based on SQL syntax.

\subsubsection{Output}

After selecting the required datasets for download, the output is prepared according to the data and metadata standards of the Coordinated Energy and water cycle Observations Project $(\mathrm{CEOP})^{6},{ }^{7}$. CEOP's main goal is to understand and predict continental to local-scale hydroclimates for hydrologic applications and coordination of the regional hydroclimate projects. CEOP has accelerated the adoption of standards for various types of observations, including those of soil moisture. These standards do not only specify the formats of the data (Table 3) but also provide prescriptions on metadata formats and file naming conventions. Metadata descriptions compliant with ISO 19115 and INSPIRE (Infrastructure for Spatial Information in the European Community $)^{8}$ are directly retrieved from the database and saved in an XML file that is appended to the data download.

\footnotetext{
${ }^{6}$ CEOP is renamed GEWEX Hydroclimatology Project since September, 2010.

${ }^{7}$ http://www.eol.ucar.edu/projects/ceop/dm/documents/ refdata_report/

${ }^{8} \mathrm{http}: / /$ inspire.jrc.ec.europa.eu/
}

\subsection{Data harmonization}

Datasets provided by participating networks (Sect. 4) are harmonized in time and with respect to the measurement units.

\subsubsection{Temporal resampling}

The various networks and stations measure at different temporal sampling intervals. Whereas the datasets contained in the Global Soil Moisture Data Bank (Robock et al., 2000) supply only several observations per month, most modern automated stations provide several measurements per hour (Sect. 4). Following recommendations from the World Meteorological Organization, co-sponsored programs and applications for satellite soil moisture products ${ }^{9}$, we decided that for the ISMN a temporal resolution of 1 hour is sufficient for all applications, including regional numerical weather prediction.

Observation datasets, which are available at sub-hourly sampling rates, have been thinned selecting the individual measurements at the hourly UTC reference time step (Table 4). If at this hourly sampling interval no measurement is available (e.g., indicated by a dummy value like “-99.90"), the database entry will receive the value "NaN" (Not a Number). This is illustrated in Table 4 for the time step 18:00 UTC. If no valid measurement is available, which means that the measurement value is outside a plausible range, the database entry for this measurement is labeled with a quality flag (see Sect. 3.4 for details). The thinning

\footnotetext{
${ }^{9}$ http://www.wmo.int/pages/prog/sat/Requirements/ Observational-requirements_web.xls
} 


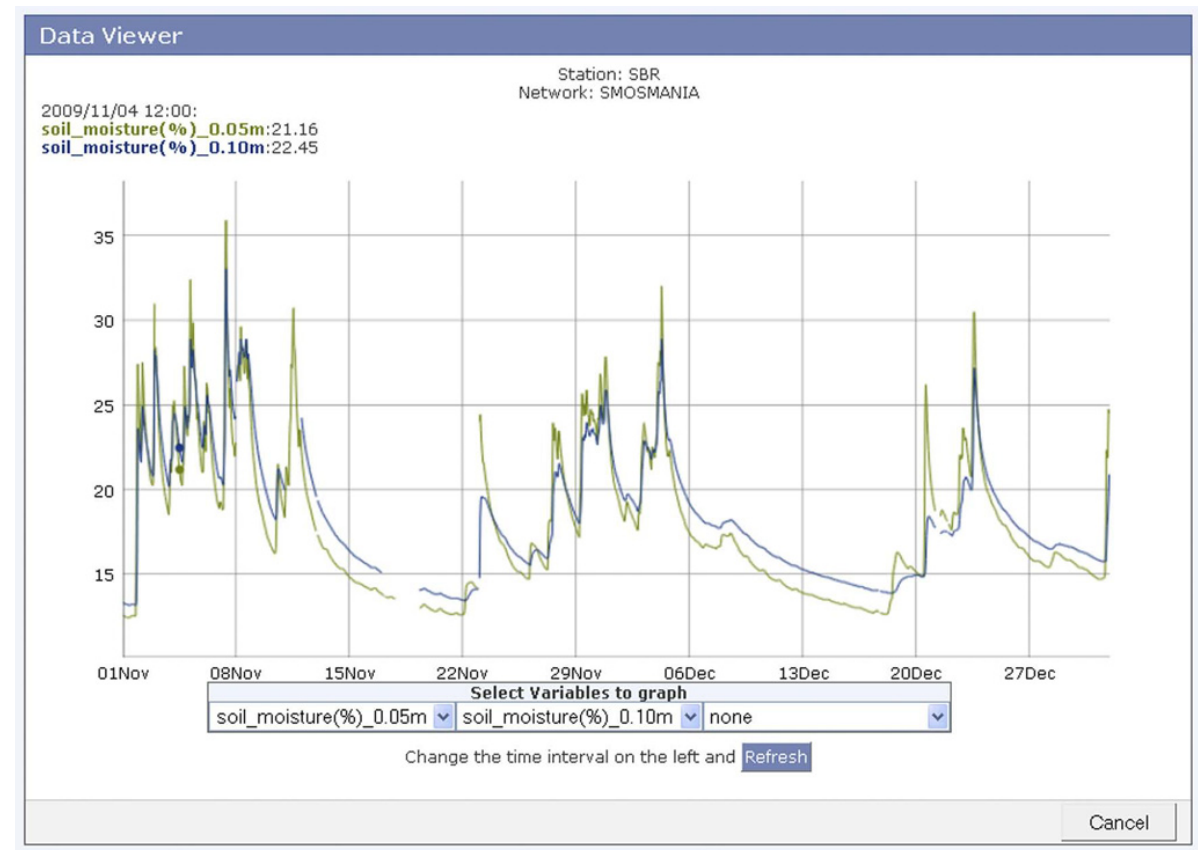

Fig. 3. Data viewer window with an example of soil moisture data from the SMOSMANIA network, Sabres station.

Table 3. CEOP Soil Temperature and Soil Moisture Dataset Format Definition.

\begin{tabular}{lcrl}
\hline Variable name & C format & Missing Value & Final Units/Equations/Notes \\
\hline UTC Nominal Date/Time & 16 chars & N/A & yyyy/mm/dd HH:MM, where MM is 00 or 30, only \\
UTC Actual Date/Time & 16 chars & N/A & yyyy/mm/dd HH:MM \\
CSE Identifier & 10 chars & N/A & Fill name with underscores, not spaces. \\
Reference Site Identifier & 15 chars & N/A & Fill name with underscores, not spaces. \\
Station Identifier & 15 chars & N/A & Fill name with underscores, not spaces. \\
Latitude & $\mathrm{f} 10.5$ & -99.99999 & decimal degrees. South is negative. \\
Longitude & $\mathrm{f} 11.5$ & -999.99999 & decimal degrees. West is negative. \\
Elevation & $\mathrm{f7.2}$ & -999.99 & meters \\
Sensor Height & $\mathrm{f7.2}$ & -999.99 & meters; height of sensor. Positive above ground level. \\
& & & Negative below ground. \\
Soil Temperature & $\mathrm{f} 8.2$ & -999.99 & Celsius \\
Soil Temperature Flag & 1 char & $\mathrm{M}$ & See Sect. 3.4 \\
Soil Moisture & $\mathrm{f} 8.2$ & -999.99 & Percent. Volumetric water content. \\
Soil Moisture Flag & 1 char & M & See Sect. 3.4 \\
\hline
\end{tabular}

also has the advantage that the data amount is significantly reduced, thus leading to a better performance of the database.

The proposed temporal resampling scheme is applied to all included meteorological variables, except for precipitation. For precipitation, which is a flux and not a state variable, all valid measurements taken since the penultimate database entry are added up for the respective time interval.

\subsubsection{Harmonizing soil moisture}

All soil moisture measurements provided to the ISMN are stored in the database as fractional volumetric soil moisture $\left(\mathrm{m}^{3} \mathrm{~m}^{-3}\right)$ which is the most commonly used unit (Sect. 2.1). Most current networks provide their data in volumetric soil moisture (either in $\mathrm{m}^{3} \mathrm{~m}^{-3}$ or $\%$ ) so often no conversion is needed. However, most historical networks provide soil moisture in a different unit or definition and hence these observations need to be converted. This is done according to the equations in Table 5. For the conversion additional metadata are required.

We decided not to harmonize soil moisture measurements in the vertical direction (depth). A harmonization in terms of depths is considered infeasible, as all networks operate their 
Table 4. Temporal resampling: example for soil moisture measurements

\begin{tabular}{lrcc}
\hline \multicolumn{2}{c}{ Original measurements } & \multicolumn{2}{c}{ Database entry } \\
\hline Date/time & value & Date/time & value \\
28/04/2006 16:20 & 17.58 & no entry & no entry \\
28/04/2006 16:40 & 17.49 & no entry & no entry \\
$28 / 04 / 200617: 00$ & 17.30 & $28 / 04 / 200617: 00$ & 17.30 \\
$28 / 04 / 200617: 20$ & 16.83 & no entry & no entry \\
28/04/2006 17:40 & 16.62 & no entry & no entry \\
28/04/2006 18:00 & -99.90 & $28 / 04 / 200618: 00$ & NaN \\
$28 / 04 / 200618: 20$ & -16.20 & no entry & no entry \\
$28 / 04 / 200618: 40$ & NaN & no entry & no entry \\
28/04/2006 19:00 & -0.01 & $28 / 04 / 200619: 00$ & -0.01 \\
\hline
\end{tabular}

Table 5. Equations used to convert original soil moisture unit into volumetric water content $\Theta$ (\% volume).

\begin{tabular}{|c|c|}
\hline Measurement unit & Conversion equation \\
\hline $\begin{array}{l}\text { Gravimetric water content } \\
(\mathrm{w}) \text {, defined as the ratio } \\
\text { between the mass of water } \\
\text { and the mass of solids }\end{array}$ & $\begin{array}{l}\Theta=\mathrm{W} \cdot \rho_{\mathrm{b}} / \rho_{\mathrm{W}} \\
\rho_{\mathrm{b}} \text { dry bulk density (variable) } \\
\rho_{\mathrm{W}}: \text { water density (assumed } \\
1000 \mathrm{~kg} \mathrm{~m}^{-3} \text { ) }\end{array}$ \\
\hline $\begin{array}{l}\text { Degree of saturation }(s) \text {, } \\
\text { defined as the volume of water } \\
\text { relative to the volume of voids. }\end{array}$ & $\begin{array}{l}\Theta=P \cdot s \\
P: \text { total porosity }\end{array}$ \\
\hline $\begin{array}{l}\text { Equivalent Depth of Water per } \\
\text { Depth of Soil }\left(D_{\text {eq }}\right) \text {, } \\
\text { calculated by multiplying the } \\
\text { volumetric water content } \Theta \\
\text { with a depth interval } \Delta z .\end{array}$ & $\Theta=\Delta z / D_{\mathrm{eq}}$ \\
\hline Plant available water, PAW & $\begin{array}{l}\Theta=P A W+\Theta_{\mathrm{wp}} \\
\Theta_{\mathrm{wp}} \text { : permanent wilting point }\end{array}$ \\
\hline $\begin{array}{l}\text { Water volume ratio } \\
\text { (sometimes called liquid } \\
\text { ratio), } v_{\mathrm{w}} \text {, expressed by } \\
\text { the volume of water divided } \\
\text { by the volume of soil. }\end{array}$ & $\begin{array}{l}\Theta=v_{\mathrm{W}} /(1+e) \\
e: \text { void ratio. }\end{array}$ \\
\hline
\end{tabular}

sensors in different ways (horizontal and vertical measurements, point vs. interval measurements, etc.) and depths. Harmonizing the data to one or several fixed depths would require either assumptions or supplemental modeling that would require information about the profile that is not available. In addition, since there are many potential uses for the data, there is no general agreement on the optimum depths of soil moisture measurements to provide. For example, satellite validation and calibration typically require observations of the $0-5 \mathrm{~cm}$ layer while for evaluation of land surface models required measurement depths depend on the definition of the depth intervals of the different layers.
Table 6. CEOP quality flags adopted by the ISMN.

\begin{tabular}{cl}
\hline Flag value & Definition \\
\hline C & $\begin{array}{l}\text { Reported value exceeds output format } \\
\text { field size OR was negative precipitation. }\end{array}$ \\
M & $\begin{array}{l}\text { Parameter value missing OR derived } \\
\text { parameter can not be computed. }\end{array}$ \\
D & Questionable/dubious \\
U & Unchecked \\
\hline
\end{tabular}

Table 7. Plausible variable ranges for the meteorological data stored in the ISMN. Values 1 exceeding this range are marked with the CEOP flag "C".

\begin{tabular}{lr}
\hline Variable name & Variable range \\
\cline { 2 - 2 } Soil moisture & $0-0.6 \mathrm{~m}^{3} \mathrm{~m}^{-3}$ \\
Soil temperature & $-60-60^{\circ} \mathrm{C}$ \\
Air temperature & $-60-60^{\circ} \mathrm{C}$ \\
Precipitation & $0-100 \mathrm{~mm} \mathrm{~h}^{-1}$ \\
Soil suction* & $0-2500 \mathrm{kPa}$ \\
\hline
\end{tabular}

* Based on Fredlund and Rahardjo (1993).

\subsection{Quality flagging}

Quality flagging of the data is based on the CEOP-Data Flag Definitions ${ }^{10}$. At present, it is not a common practice that soil moisture networks provide quality indicators with their data. Therefore, we decided to integrate the allocation of quality indicators in the data hosting facility itself. A rather conservative quality checking scheme was implemented, so that suspect observations can be detected more easily. We decided to provide only quality indicators that can be checked in an objective way. Hence, indicators like "Bad" and "Good" are not included. This leads to the subset of CEOP quality flags presented in Table 6 .

Table 7 shows the possible ranges for the most important meteorological variables. If a measured data value exceeds this range (on either side of the range) the measurement receives the flag value "C." If a measurement is missing, its quality flag is set to "M." All other dataset values have been set to "U" for unchecked.

In contrast to the other meteorological measurements, for soil moisture also the quality flag "Questionable/Dubious (D)" is adopted. This quality flag is adopted when a soil moisture measurement in combination with another variable leads to a suspicious result (Table 8).

\footnotetext{
${ }^{10} \mathrm{http} / / / \mathrm{www}$.eol.ucar.edu/projects/ceop/dm/documents/ refdata_report/data_flag_definitions.html
} 


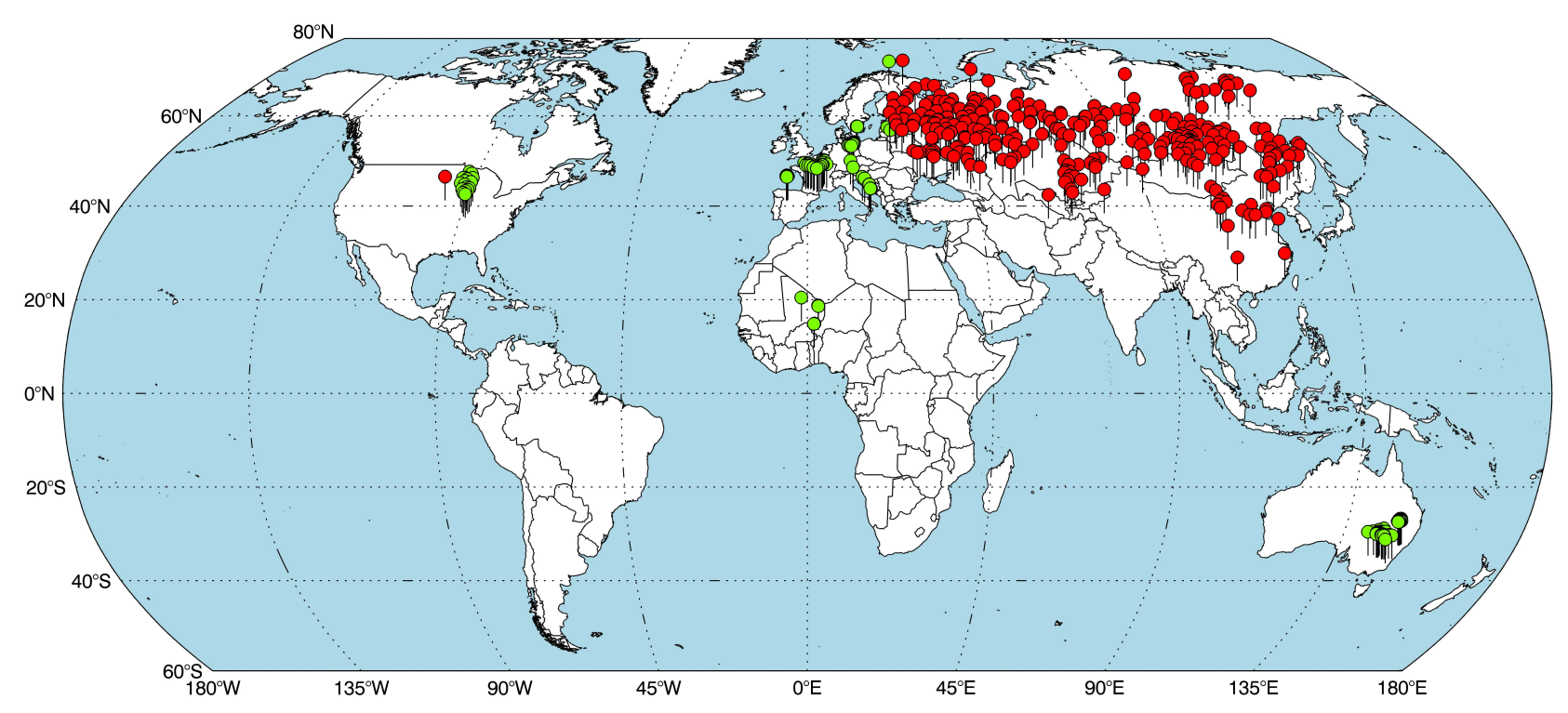

Fig. 4. Map of the distribution of networks and stations contained in the ISMN (Situation of May 2011). Green pins indicate active stations, red pins the historical data sets inherited from the Global Soil Moisture Data Bank (Robock et al., 2000).

If networks themselves provide CEOP-based quality flags with their data, these are propagated to the data hosting facility. Thus, the list of quality flags might be extended with the other CEOP flags in a future version of the database. In case a quality flag provided by a network conflicts with the one attributed by the ISMN, the most restrictive one is always adopted (e.g., if a contributing network sets the flag "Good" and the quality control of the ISMN typifies a measurement as "Dubious," the latter will be taken over by the database).

\section{Soil moisture datasets currently contained in the ISMN}

The soil moisture and meteorological datasets contained in the ISMN are shared by the network operating organizations on a voluntary basis and free of cost. At present (status May 2011), the ISMN contains the data of 9 networks which together contain more than 500 stations. The spatial distribution of the stations is presented in Fig. 4. Apart from several recently established operational networks that share their data with the ISMN, the Global Soil Moisture Data Bank (Robock et al., 2000) merged its data collection with the ISMN and has now been closed.

The following paragraphs describe the individual networks, which are listed in alphabetical order. The overview of the datasets presented here is just a snapshot of the current situation while the ISMN is continuously evolving. Several other networks have already announced their participation and will be included in the near future. To keep up to date with the most recent developments, we advise regular visits to the news section of the ISMN or a subscription to the newsletter (see http://www.ipf.tuwien.ac.at/insitu/ for more details).

\subsection{AMMA}

Soil moisture data from this network have been collected within The African Monsoon Multidisciplinary Analysis (AMMA) ${ }^{11}$ experiment, which is an international and interdisciplinary cooperation designed to investigate the interactions between atmospheric, oceanic and terrestrial systems and their joint controls on tropical monsoon dynamics in West Africa (Lebel et al., 2009). The soil moisture stations are located in three mesoscale sites in three different countries sampling the West-African eco-climatic gradient. For the Mali station, soil moisture measurements at a given depth have been taken at the bottom, middle, and top of a sand dune. In Niger, the stations were positioned in a way to describe the gradient from a plateau down to the valley bottom. More details on the AMMA network and project details are found in various publications (Cappelaere et al., 2009; de Rosnay et al., 2009; Mougin et al., 2009; Pellarin et al., 2009a) and in Table 9. Soil moisture measurement taken at the AMMA sites have been extensively used for satellite product validation (e.g., Gruhier et al., 2008, 2010; Pellarin et al., 2009b; Zribi et al., 2009) and hydrological modeling (Pellarin et al., 2009a).

\subsection{CALABRIA}

The stations of the CALABRIA network are found on various locations across the Calabria region in southern Italy.

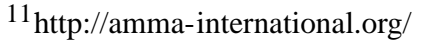


Table 8. Parameter combinations leading to CEOP quality flag "D" for soil moisture.

\begin{tabular}{ll}
\hline 1 Valid soil moisture measurement in combination with a \\
negative soil temperature (measured at same depth) \\
2 Valid surface soil moisture measurement in combination \\
with a negative air temperature \\
3 A decreasing or stable surface soil moisture content \\
(with respect to the previous time step) while \\
precipitation is measured
\end{tabular}

The network was installed by the Centro Funzionale Multirischi - ARPACAL $12^{12}$ for civil protection activities related to hydrometeorological monitoring for flood and landslide risk mitigation. More details on this network are found in Brocca et al. (2011) and Table 9. Soil moisture measurements provided by this network have been used for the validation of various satellite-based soil moisture products from AMSR-E and ASCAT (Brocca et al., 2011).

\subsection{CAMPANIA}

The CAMPANIA network is located near the city of Naples in the Campania region in southern Italy. The data are measured and prepared by the Centro Funzionale per la Previsione Meteorologica e il Monitoraggio Meteo-PluvioIdrometrico e delle Frane, Settore Programmazione Interventi di Protezione Civile sul Territorio, Regione Campania. ${ }^{13}$ Details on the measurements performed in this network are found in Brocca et al. (2011) and Table 9. Soil moisture measurements provided by this network have been used for the validation of various satellite-based soil moisture products from AMSR-E and ASCAT (Brocca et al., 2011)

\subsection{CHINA}

This dataset was previously contained in the Global Soil Moisture Data Bank (Robock et al., 2000). The observations were taken at the 8,18 and 28th of each month during the period 1981-1999 and served agricultural purposes. For some stations, no measurements were taken in the cold season due to the frozen surface. Despite the low sampling rate, the soil moisture measurements provide detailed information on the vertical distribution of soil water as measurements were taken at 11 depth intervals over the upper $1 \mathrm{~m}$ soil layer. More details are found in Table 9 and Robock et al. (2000). Data from the CHINA network have been extensively used for a large range of applications, including fundamental research on the behavior of soil moisture (e.g., Entin et al., 2000), improvement of land surface and reanalysis models

\footnotetext{
${ }^{12}$ http://www.cfcalabria.it/

${ }^{13} \mathrm{http}: / /$ www.regione.campania.it/
}

(e.g., Rodell et al., 2004), evaluating drought severity models (e.g., Dai et al., 2004), and satellite soil moisture product validation (e.g., Reichle et al., 2004).

\subsection{CNR-IRPI}

The CNR-IRPI network is located near the city of Perugia in central Italy. The network is maintained by the Research Institute for Geo-Hydrological Protection (IRPI) of the Italian National Research Council (CNR) ${ }^{14}$ to serve flood forecasting. Additional information on the sites can be found in Table 9 and in Brocca et al. (2008, 2009). Data from the CNR-IRPI network have been used to test the reliability of various AMSR-E and ASCAT-based soil moisture products (Brocca et al., 2010b, 2011; Liu et al., 2011) and to study the spatio-temporal dynamics of soil moisture (Brocca et al., 2007, 2010a).

\subsection{FMI}

This network is operated by the Finish Meteorological Institute (FMI) as part of an operational weather observatory. Currently it consists of a single station (FMI Arctic Research Centre in Sodankylä) ${ }^{15}$ that measures soil moisture in a fully automated operational mode at three different locations a few meters apart. The network has participated in several international projects and initiatives, such as FLUXNET (Baldocchi et al., 2001) and the validation of diverse SMOS products (Rautiainen et al., 2011). More information on the FMI can be found in Rautiainen et al. (2011) and in Table 9. The FMI network is the first network in the ISMN that provides updates on a fully automated basis. Once a day, data sets are downloaded from the FMI server, processed and quality controlled, and ingested into the database of the ISMN. Data sets of the FMI network were used for studying the relationship between soil moisture and microwave emissions and backscatter in L-., C-, and X-band (Pulliainen et al., 1994; Rautiainen et al., 2011).

\subsection{ICN}

The Illinois Climate Network (ICN) ${ }^{16}$ is coordinated by the Water and Atmospheric Resources Program of the Illinois State Water Survey. This network was also contained in the Global Soil Moisture Data Bank. Measurements began in 1981 and the network continues to operate until present. The main purpose of the network is to provide information on extreme and usual weather events, as well as short and longterm trends in climate data. The dataset contained in the ISMN covers the period 1983 through July 2008 while an update with the most recent datasets is foreseen for the near future. The first two years were removed because of spin-up

\footnotetext{
${ }^{14}$ http://www.irpi.cnr.it/

$15 \mathrm{http} / / / \mathrm{fmiarc}$. fmi.fi/index.html

${ }^{16} \mathrm{http}: / / \mathrm{www} . i \mathrm{sws}$. illinois.edu/warm.
} 
Table 9. Overview of networks contained in ISMN (Status May 2011).

\begin{tabular}{|c|c|c|c|}
\hline Network name & AMMA & CALABRIA & CAMPANIA \\
\hline Country & Benin, Mali, Niger & Italy & Italy \\
\hline Number of stations & 7 & 5 & 2 \\
\hline Variables measured & Soil moisture $\left[\mathrm{m}^{3} \mathrm{~m}^{-3}\right]$ & $\begin{array}{l}\text { Soil moisture }\left[\mathrm{m}^{3} \mathrm{~m}^{-3}\right], \\
\text { air temperature at } 2 \mathrm{~m}\left[{ }^{\circ} \mathrm{C}\right] \text {, } \\
\text { precipitation }[\mathrm{mm}]\end{array}$ & $\begin{array}{l}\text { Soil moisture }\left[\mathrm{m}^{3} \mathrm{~m}^{-3}\right], \\
\text { air temperature at } 2 \mathrm{~m}\left[{ }^{\circ} \mathrm{C}\right] \text {, } \\
\text { precipitation }[\mathrm{mm}]\end{array}$ \\
\hline $\begin{array}{l}\text { Depths of soil moisture } \\
\text { measurements }\end{array}$ & $\begin{array}{l}0.05 \mathrm{~m}, 0.10 \mathrm{~m}, 0.10-0.40 \mathrm{~m}, 0.20 \mathrm{~m}, \\
0.30 \mathrm{~m}, 0.40 \mathrm{~m}, 0.40-0.70 \mathrm{~m}, 0.60 \mathrm{~m}, \\
0.70-1.00 \mathrm{~m}, 1.00 \mathrm{~m}, 1.00-1.30 \mathrm{~m}, \\
1.05-1.35 \mathrm{~m}, 1.20 \mathrm{~m}\end{array}$ & $0.30 \mathrm{~m}, 0.60 \mathrm{~m}, 0.90 \mathrm{~m}$ & $0.30 \mathrm{~m}$ \\
\hline Soil moisture instrument & CS 616 (Campbell Scientific) & $\begin{array}{l}\text { ThetaProbe ML2X } \\
\text { (Delta-T Device) }\end{array}$ & $\begin{array}{l}\text { ThetaProbe ML2 } \\
\text { (Delta-T Devices) }\end{array}$ \\
\hline Data availability & 1 January 2006-31 December 2009 & 1 January 2001-31 May 2010 & $\begin{array}{l}26 \text { November } 2000- \\
31 \text { December } 2008\end{array}$ \\
\hline Original sampling interval & $15 \min$ & $20 \mathrm{~min}$ & $60 \mathrm{~min}$ \\
\hline Land cover/land use & $\begin{array}{l}\text { Natural rangeland, crops, } \\
\text { wooded savanna }\end{array}$ & Crops, forest, grassland & Agriculture (grassland), forest \\
\hline Available soil metadata & Soil texture & - & Soil texture \\
\hline
\end{tabular}

Table 9 Continued. Overview of networks contained in ISMN (Status May 2011).

\begin{tabular}{|c|c|c|c|}
\hline Network name & CHINA & CNR-IRPI & FMI \\
\hline Country & China & Italy & Finland \\
\hline Number of stations & 40 & 4 & 1 \\
\hline Variables measured & Soil moisture $[\mathrm{cm}]$ & $\begin{array}{l}\text { Soil moisture }\left[\mathrm{m}^{3} \mathrm{~m}^{-3}\right] \text {, } \\
\text { air temperature at } 2 \mathrm{~m}\left[{ }^{\circ} \mathrm{C}\right] \text {, } \\
\text { precipitation }[\mathrm{mm}]\end{array}$ & $\begin{array}{l}\text { Soil moisture }\left[\mathrm{m}^{3} \mathrm{~m}^{-3}\right] \text {, } \\
\text { soil temperature }\left[{ }^{\circ} \mathrm{C}\right], \\
\text { air temperature at } 2 \mathrm{~m} \\
{\left[{ }^{\circ} \mathrm{C}\right]}\end{array}$ \\
\hline $\begin{array}{l}\text { Depths of soil moisture } \\
\text { measurements }\end{array}$ & $\begin{array}{l}0.00-0.05 \mathrm{~m}, 0.05-0.10 \mathrm{~m}, \\
0.10-0.20 \mathrm{~m}, 0.20-0.30 \mathrm{~m}, \\
0.30-0.40 \mathrm{~m}, 0.40-0.50 \mathrm{~m}, \\
0.50-0.60 \mathrm{~m}, 0.60-0.70 \mathrm{~m} \\
0.70-0.80 \mathrm{~m}, 0.80-0.90 \mathrm{~m} \\
0.90-1.00 \mathrm{~m}\end{array}$ & $\begin{array}{l}0.05-0.15 \mathrm{~m}, 0.15-0.25 \mathrm{~m} \\
0.35-0.45 \mathrm{~m}\end{array}$ & $0.02 \mathrm{~m}, 0.10 \mathrm{~m}$ \\
\hline Soil moisture instrument & Coring device/auger & $\begin{array}{l}\text { EnviroSCAN } \\
\text { (Sentek Technologies) }\end{array}$ & ThetaProbe ML2X \\
\hline Data availability & 8 January 1981-28 December 1999 & 9 October 2002-31 May 2008 & 25 January 2005-present \\
\hline Original sampling interval & 10-11 days & $30 \mathrm{~min}$ & $1 \mathrm{~h}$ \\
\hline Land cover/land use & $\begin{array}{l}\text { Agricultural (e.g. winter wheat, maize, } \\
\text { sorghum, beans) }\end{array}$ & Agricultural, pasture & Boreal forest \\
\hline Available soil metadata & Permanent wilting points & - & Texture \\
\hline
\end{tabular}


Table 9 Continued. Overview of networks contained in ISMN (Status May 2011).

\begin{tabular}{|c|c|c|c|}
\hline Network name & $\mathrm{ICN}$ & IOWA & MOL-RAO \\
\hline Country & United States & United States & Germany \\
\hline Number of stations & 19 & 6 & 2 \\
\hline Variables measured & Soil moisture [mm] & Soil moisture [\% vol] & $\begin{array}{l}\text { Soil moisture }[\% \mathrm{vol}] \\
\text { soil temperature }\left[{ }^{\circ} \mathrm{C}\right] \\
\text { air temperature at } 2 \mathrm{~m}\left[{ }^{\circ} \mathrm{C}\right] \text {, } \\
\text { precipitation }[\mathrm{mm}]\end{array}$ \\
\hline $\begin{array}{l}\text { Depths of soil moisture } \\
\text { measurements }\end{array}$ & $\begin{array}{l}0.00-0.10 \mathrm{~m}, 0.10-0.30 \mathrm{~m}, \\
0.30-0.50 \mathrm{~m}, 0.50-0.70 \mathrm{~m}, \\
0.70-0.90 \mathrm{~m}, 0.90-1.10 \mathrm{~m}, \\
1.10-1.30 \mathrm{~m}, 1.30-1.50 \mathrm{~m}, \\
1.50-1.70 \mathrm{~m}, 1.70-1.90 \mathrm{~m}, \\
1.90-2.00 \mathrm{~m}\end{array}$ & $\begin{array}{l}0.00-0.07 \mathrm{~m}, 0.07-0.15 \mathrm{~m} \\
0.15-0.30 \mathrm{~m}, 0.30-0.45 \mathrm{~m} \\
0.45-0.68 \mathrm{~m}, 0.68-0.83 \mathrm{~m} \\
0.83-1.06 \mathrm{~m}, 1.06-1.37 \mathrm{~m} \\
1.37-1.67 \mathrm{~m}, 1.67-1.98 \mathrm{~m} \\
1.98-2.28 \mathrm{~m}, 2.28-2.59 \mathrm{~m}\end{array}$ & $\begin{array}{l}0.08 \mathrm{~m}, 0.10 \mathrm{~m}, 0.15 \mathrm{~m}, \\
0.20 \mathrm{~m}, 0.30 \mathrm{~m}, 0.45 \mathrm{~m}, \\
0.60 \mathrm{~m}, 0.90 \mathrm{~m}, 1.50 \mathrm{~m}\end{array}$ \\
\hline Soil moisture instrument & $\begin{array}{l}\text { Neutron Depth Probe (Troxler), } \\
\text { Neutron Surface Probe (Troxler) }\end{array}$ & $\begin{array}{l}\text { Coring device/auger, } \\
\text { neutron probe }\end{array}$ & $\begin{array}{l}\text { TRIME-EZ TDR Sensor } \\
\text { (IMKO GmbH) }\end{array}$ \\
\hline Data availability & $\begin{array}{l}1 \text { January } 1981- \\
15 \text { July } 2008\end{array}$ & $\begin{array}{l}4 \text { April } 1972- \\
15 \text { November } 1994\end{array}$ & $\begin{array}{l}1 \text { January 2003- } \\
31 \text { December } 2008\end{array}$ \\
\hline Original sampling interval & $\begin{array}{l}\text { 14-16 days (growing season); } \\
28-31 \text { days (rest of the year) }\end{array}$ & 15 days (growing season) & $30 \mathrm{~min}$ \\
\hline Land cover/land use & Grassland, bare soil & Agricultural crops & Grassland, forest (pine) \\
\hline Available soil metadata & $\begin{array}{l}\text { Field capacity, permanent wilting } \\
\text { point, potential plant available water }\end{array}$ & None & $\begin{array}{l}\text { Texture, bulk density, poros- } \\
\text { ity, wilting points, hydraulic } \\
\text { conductivity, heat capacity }\end{array}$ \\
\hline
\end{tabular}

Table 9 Continued. Overview of networks contained in ISMN (Status May 2011).

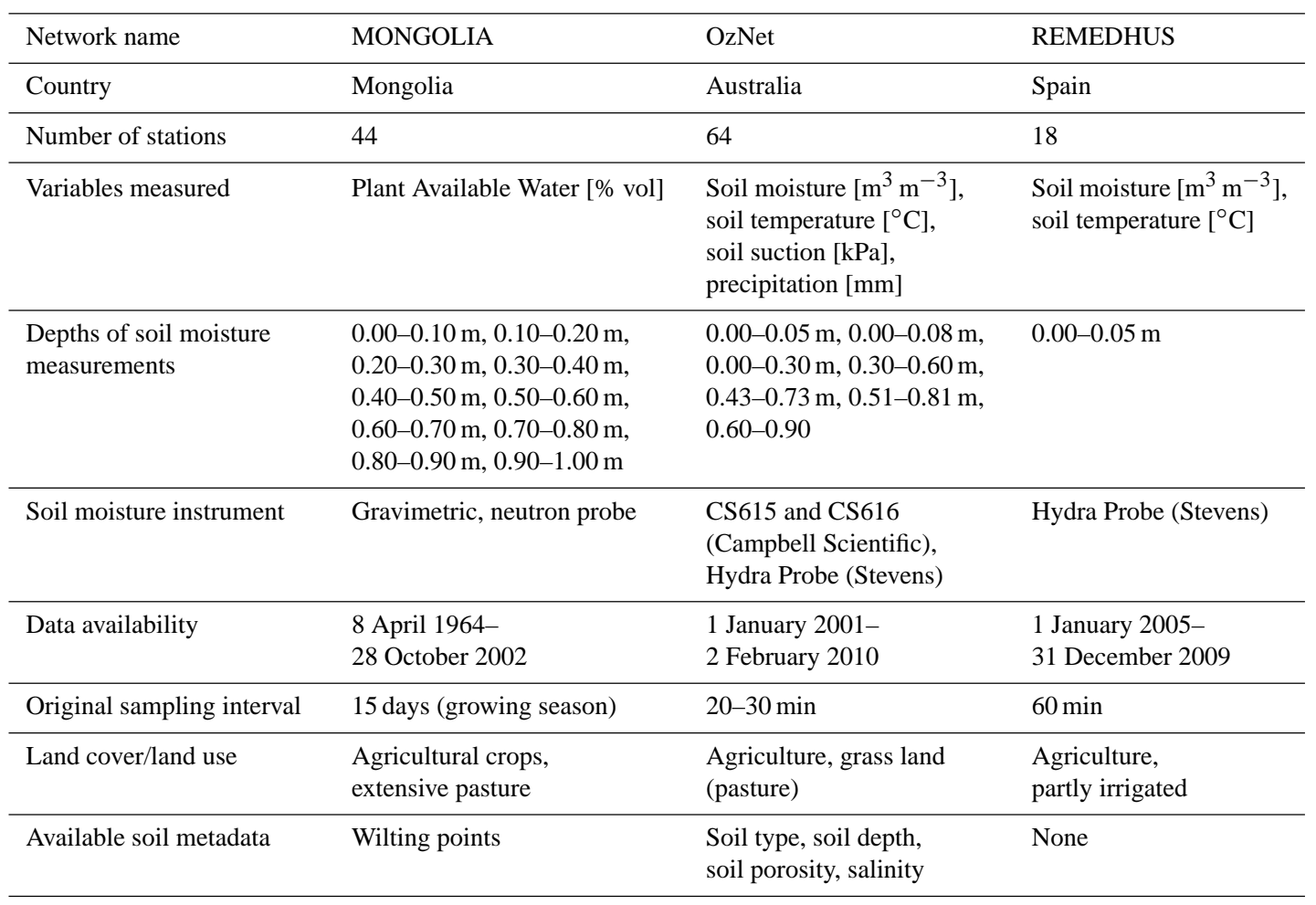


Table 9 Continued. Overview of networks contained in ISMN (Status May 2011).

\begin{tabular}{|c|c|c|c|}
\hline Network name & RUSWET-AGRO & RUSWET-GRASS & RUSWET-VALDAI \\
\hline Country & $\begin{array}{l}\text { Russia, Belarus, Moldova, Lithuania, } \\
\text { Latvia, Estonia, Kazakhstan }\end{array}$ & $\begin{array}{l}\text { Russia, Belarus, Kazakhstan, } \\
\text { Uzbekistan, Turkmenistan, } \\
\text { Tajikistan }\end{array}$ & Russia \\
\hline Number of stations & 78 & 122 & 3 \\
\hline Variables measured & $\begin{array}{l}\text { Plant available water } \\
\text { [volumetric \%] }\end{array}$ & $\begin{array}{l}\text { Plant available water } \\
\text { [volumetric \%] }\end{array}$ & $\begin{array}{l}\text { Soil moisture [volumetric \%], } \\
\text { precipitation }[\mathrm{mm}], \\
\text { soil temperature }\left[{ }^{\circ} \mathrm{C}\right] \text {, } \\
\text { air temperature }\left[{ }^{\circ} \mathrm{C}\right] \\
\text { water table depth }[\mathrm{cm}] \\
\text { snow water equivalent }[\mathrm{mm}]\end{array}$ \\
\hline $\begin{array}{l}\text { Depths of soil moisture } \\
\text { measurements }\end{array}$ & $0.00-0.20 \mathrm{~m}, 0.00-1.00 \mathrm{~m}$ & $0.00-0.10 \mathrm{~m}, 0.00-1.00 \mathrm{~m}$ & $\begin{array}{l}0.00-0.20 \mathrm{~m}, 0.00-0.50 \mathrm{~m} \\
0.00-1.00 \mathrm{~m}\end{array}$ \\
\hline Soil moisture instrument & Gravimetric & Gravimetric & Gravimetric \\
\hline Data availability & 28 December 1986-28 December 1988 & January 1952-December 1985 & January 1952-December 1985 \\
\hline Original sampling interval & 10-11 days (growing season) & $\begin{array}{l}\text { 10-11 days (growing season); } \\
28-31 \text { days (rest of year) }\end{array}$ & 1 month \\
\hline Land cover/land use & $\begin{array}{l}\text { Spring cereal crops and winter cereal } \\
\text { crops }\end{array}$ & Natural grassland & Grassland, Forest \\
\hline Available soil metadata & Wilting points & Wilting points & Wilting points \\
\hline
\end{tabular}

Table 9 Continued. Overview of networks contained in ISMN (Status May 2011).

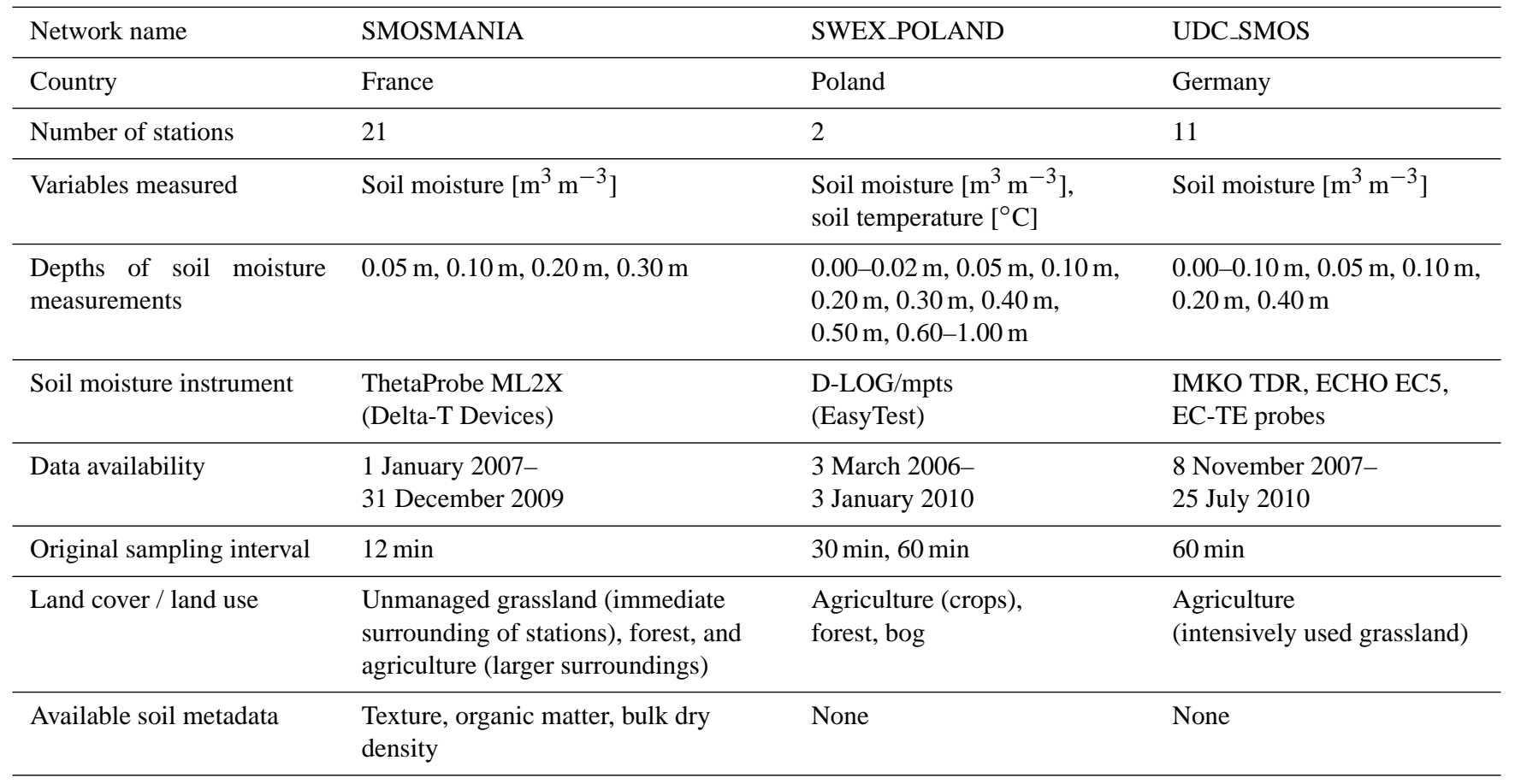


Table 9 Continued. Overview of networks contained in ISMN (Status May 2011).

\begin{tabular}{ll}
\hline $\begin{array}{l}\text { Network name } \\
\text { Country }\end{array}$ & UMSUOL \\
Number of stations & 1 \\
Variables measured & Soil moisture $\left[\mathrm{m}^{3} \mathrm{~m}^{-3}\right]$ \\
Depths of soil moisture & $0.10 \mathrm{~m}, 0.25 \mathrm{~m}, 0.45 \mathrm{~m}$, \\
measurements & $0.70 \mathrm{~m}, 1.00 \mathrm{~m}, 1.35 \mathrm{~m}$, \\
& $1.80 \mathrm{~m}$ \\
Soil moisture instrument & TDR $100($ Campbell $)$ \\
Data availability & 1 June $2009-$ \\
& 1 October 2010 \\
Original sampling & 60 min \\
interval & \\
Land cover/land use & Grassland \\
Available soil metadata & Organic matter content, \\
& texture, bulk density \\
\hline
\end{tabular}

issues as the sensors were installed. Despite the low temporal sampling frequency (1-2 times per month, depending on the time of the year), the large number of depth intervals facilitates studying the vertical behavior of soil moisture over time. Further details on the network can be found in Table 9 and Hollinger and Isard (1994). Apart from climate research (e.g., Hollinger and Isard, 1994; Robock et al., 2000), several scientific disciplines already benefited form this network including the evaluation of land surface fluxes and state datasets (e.g., Findell and Eltahir, 1997; Dirmeyer, 2000; Maurer et al., 2002), the assessment of drought severity models (e.g., Dai et al., 2004), evaluation of climate models (e.g., Robock et al., 1998; Oleson et al., 2008), long-term weather forecasting (e.g., Huang et al., 1996), designing soil moisture observational networks (e.g., Vinnikov et al., 1999a) and satellite soil moisture product validation (e.g., Vinnikov et al., 1999b; Owe et al., 2001; Njoku et al., 2003; Reichle et al., 2004; Owe et al., 2008).

\subsection{IOWA}

The IOWA dataset was transferred from the Global Soil Moisture Data Bank and consists of soil moisture observations from two different catchments located in the southwest of Iowa. Soil moisture observations were taken for scientific purposes until 1994 when it ceased operation. The gravimetric method was used to measure soil moisture for the top 5 layers, neutron probes for the deeper layers. On average, observations were made twice a month between April and October. More information about this network can be found in Table 9, Entin et al. (2000), and Robock et al. (2000). The IOWA dataset has been used e.g. for trend analysis in soil moisture (Robock et al., 2000), satellite product validation (Reichle et al., 2004) and for studying the temporal and spatial scales of soil moisture dynamics (Entin et al., 2000).

\subsection{Lindenberg Meteorological Observatory}

The Lindenberg Meteorological Observatory - Richard Assmann Observatory (MOL-RAO $)^{17}$ is situated close to Berlin, Germany. It is operated by the German Meteorological Service DWD and perfoms systematic observations of the atmosphere and the land surface. Soil moisture is operationally measured at a grassland site (Falkenberg) and a forest site (Kerigh) since 1998 and 2002, respectively. Being part of an operational meteorological observatory, also several other relevant hydrometeorological variables are provided and soil properties are well documented. Information on the network can be found in Table 9, in Beyrich and Adam (2007) and in various web sources ${ }^{18}$. Soil moisture data of the MOL-RAO network have been used to study the effect of soil moisture on surface heat fluxes (Beyrich et al., 2006; Heret et al., 2006).

\subsection{MONGOLIA}

Also this dataset was previously contained in the Global Soil Moisture Data Bank. Soil moisture datasets were collected by the National Agency of Meteorology, Hydrology and Environment Monitoring in Ulaanbaatar for agricultural purposes. All observations were initially provided as volumetric plant-available water. As the original measured wilting levels, required to convert PAW into fractional volumetric soil moisture content, could not be retrieved, these were calculated from soil texture and organic carbon content at each station using the predictive equations of Saxton and Rawls (2006). Input to the equations was provided by the Harmonized World Soil Database (FAO/IIASA/ISRIC/ISSCAS/JRC, 2009). Soil moisture measurements are provided three times a month during the warm period of the year, which runs from April until the end of October. More information about this network is found in Table 9 and Robock et al. (2000). Datasets of the MONGOLIA network have been extensively used in studies connected to climate variability (Robock et al., 2000), the evaluation of drought severity models (Dai et al., 2004), validation of satellite-based soil moisture products (Reichle et al., 2004), and for studying the spatial and temporal scales of soil moisture dynamics (Entin et al., 2000).

\subsection{OzNet}

The OzNet hydrological monitoring network (Table 9) consists of several smaller experimental project networks in New South Wales in southeast Australia ${ }^{19}$. The various networks are typically associated with hydrological catchments, of

\footnotetext{
${ }^{17}$ http://www.dwd.de/mol

${ }^{18} \mathrm{http}: / /$ www.eol.ucar.edu/projects/ceop/dm/insitu/sites/baltex/ lindenberg/falkenberg/,http://www.eol.ucar.edu/projects/ceop/dm/ insitu/sites/baltex/lindenberg/forest

${ }^{19} \mathrm{http}: / /$ www.oznet.org.au
} 
which the most significant are the Murrumbidgee (Young et al., 2008) and the Goulburn River catchments (Rüdiger et al., 2007). The OzNet network is managed by the University of Melbourne. Datasets from the OzNet have been extensively used for satellite product validation (Draper et al., 2009; Liu et al., 2011; Parinussa et al., 2011) and the evaluation of land surface models (Richter et al., 2004).

\subsection{REMEDHUS}

The REMEDHUS network is situated in the center of the Iberian Peninsula. It was set up in 1999 as an experimental network by the Centro Hispano Luso de Investigaciones Agrarias (CIALE) group of the University of Salamanca ${ }^{20}$. The stations lie in an agricultural area. In the vicinity of a few stations irrigation occurs. As a result, large jumps in measured soil moisture that cannot be coupled to meteorological events and very high soil moisture fractions (up to $0.95 \mathrm{~m}^{3} \mathrm{~m}^{-3}$ ) may be observed here. As irrigation usually is a very local phenomenon, the stations that are affected should be treated with caution when interpreted in a spatial context. Details of the network can be found in Table 9 and in Martínez-Fernández and Ceballos (2005). Datasets of the REMEDHUS network have been used by study the spatial and temporal dynamics of soil moisture (MartínezFernández and Ceballos, 2003, 2005) and for satellite product validation (Ceballos et al., 2005; Wagner et al., 2007; Liu et al., 2011; Parinussa et al., 2011).

\subsection{RUSWET-AGRO}

Soil moisture datasets for 78 districts in the Former Soviet Union were prepared for agricultural purposes by the Russian Hydrometeorological Center, Moscow, Russia and initially distributed through the Global Soil Moisture Databank. The soil moisture observations were originally provided as volumetric plant-available water [volumetric \%]. Due to the lag between observations and the publication of the data in reference books, and geo-political changes during the era, information on the wilting points (required to convert plant available water into volumetric soil moisture) has gone lost. To resolve this problem and make the data compatible, the predictive equations of Saxton and Rawls (2006) were used to estimate the wilting points from soil texture and organic carbon content. Input to the equations was provided by the Harmonized World Soil Database (FAO/IIASA/ISRIC/ISSCAS/JRC, 2009). As the RUSWET-AGRO dataset was designed for monitoring soil moisture at agricultural fields, datasets were separately available for spring cereal crops and winter cereal crops for all locations. In the ISMN stations with the suffix "a" represent spring cereal crops while stations with "b" illustrate winter cereal crops. Measurements are available three times a month during the growing period of 1987 and 1988. More information about this network is

\footnotetext{
${ }^{20}$ http://campus.usal.es/ $\sim$ hidrus/
}

available in Table 9, Vinnikov and Yeserkepova (1991), and Robock et al. (2000). The RUSWET-AGRO datasets have been widely used for climate research (Robock et al., 2000), evaluation of drought severity models (Dai et al., 2004), land surface model evaluation (Balsamo et al., 2009), and satellite product validation (Reichle et al., 2004).

\subsection{RUSWET-GRASS}

The RUSWET-GRASS dataset is a merger of the RUSWET130STA and RUSWET-50STA networks from the former Soviet Union previously contained in the Global Soil Moisture Data Bank. Measurements were originally used for agricultural predictions. As soil moisture was originally provided as plant available water, wilting points were needed to covert the measurements into volumetric soil moisture. Similarly as for the RUSWET-AGRO network, the predictive equations of Saxton and Rawls (2006) were used to estimate the wilting points from soil texture and organic carbon content while input to the equations was provided by the Harmonized World Soil Database (FAO/IIASA/ISRIC/ISSCAS/JRC, 2009). The dataset covers the years 1952-1985, but the spatial extent of these data is poor until about 1975 . Observations were made with a temporal resolution of about 10 days during the warm season, and once a month during winter. The provided measurements are the average of four samples taken within an area of about $1000 \mathrm{~m}^{2}$. More information on this dataset can be found in Table 9, Vinnikov and Yeserkepova (1991), and Robock et al. (2000). The RUSWET-GRASS datasets have been widely used for climate research (e.g., Robock et al., 2000), evaluation of land surface models (e.g., Robock et al., 1995, 1998; Yang et al., 1997), evaluation of drought severity models (e.g., Dai et al., 2004), and satellite product validation (e.g., Reichle et al., 2004).

\subsection{RUSWET-VALDAI}

Soil moisture datasets for 3 catchments located in the Valdai basin were collected by the State Hydrological Institute in St. Petersburg from 1960 to 1990 for water balance studies. The catchments are characterized by different types of vegetation. Soil moisture [volumetric \%] was computed using data from 9-11 observational points distributed over the basin area. The resulting files contain monthly means of soil moisture for three different depth intervals. Thus, soil moisture values are available as monthly means, precipitation as monthly totals $[\mathrm{mm}]$, and temperature $\left[{ }^{\circ} \mathrm{C}\right]$ as daily values. Other variables measured but not included into the ISMN are runoff, monthly averaged water table depth, snow water equivalent, and evaporation. More information can be found in Table 9, Vinnikov and Yeserkepova (1991), and Robock et al. (2000). The RUSWET-VALDAI datasets have been widely used for climate research (Robock et al., 2000), analysis of scales of soil moisture variation (e.g., Vinnikov et al., 
1996), evaluation of land surface models in a cold climate (Schlosser et al., 2000; Slater et al., 2001; Luo et al., 2003), evaluation of drought severity models (Dai et al., 2004), and satellite product validation (Reichle et al., 2004).

\subsection{SMOSMANIA}

The SMOSMANIA network in southern France was set up in support of calibration and validation activities for SMOS. The network is operated by the Centre National de Recherches Météorologiques, Groupe d'Etude de l'Atmosphère Météorologique (CNRM/GAME), MétéoFrance, CNRS. Initially, 12 stations were installed, but from the start of 2009 the network was extended with another 9 stations. Details of SMOSMANIA can be found in Table 9 and in Albergel et al. (2008) and Calvet et al. (2008). Measurements taken by this network have been extensively used for validating various satellite-based soil moisture products (Albergel et al., 2009, 2010; Li et al., 2010; Brocca et al., 2011; Liu et al., 2011; Parinussa et al., 2011) and for studying the interaction between surface and sub-surface soil moisture levels (Albergel et al., 2008).

\subsection{SWEX_POLAND}

The Soil Water and Energy eXchange Poland (SWEX_Poland) network is operated by the Institute of Agrophysics of the Polish Academy of Sciences. The network has been set up in particular to support calibration and validation of SMOS products over wetlands. Soil moisture and soil temperature are measured over eight different depths. More info is found in Table 9 and Marczewski et al. (2010). Primary purpose of the network will be the validation of satellite-based soil moisture retrievals (Marczewski et al., 2010).

\subsection{UDC_SMOS}

The Upper Danube Catchment SMOS network (UDC_SMOS) in Southern Germany is one of the two official European SMOS cal/val test sites. The soil moisture network is run as a cooperation between the University of Munich and the Bavarian State Research Center for Agriculture. It is funded by the German Aerospace Centre (DLR) through the project SMOSHYD ${ }^{21}$. At some stations soil moisture of a specific layer is measured by multiple sensors. Details on the UDC_SMOS network can be found in Ttable 9 and Loew et al. (2009). Loew and Schlenz (2011) used the soil moisture data of this network to quantify the uncertainties of an AMSR-E derived soil moisture product.

\footnotetext{
${ }^{21}$ http://www.geographie.uni-muenchen.de/department/fiona/ forschung/projekte/index.php?projekt_id=103
}

\subsection{UMSUOL}

UMSUOL is a network in the Po river plain in Northern Italy. It is part of an operational meteorological network operated by the Service of Hydrology, Meteorology and Climate of the Regional Agency for Environmental Protection in EmiliaRomagna (ARPA - SIMC) mainly for agricultural purposes. More information is given in Table 9. Soil moisture data of this network have been used for satellite product validation and intercomparison (Brocca et al., 2011).

\section{Discussion}

\subsection{Impact of the ISMN for satellite products and land surface models}

Even though initial funding for the establishment of the ISMN, as provided by ESA, mainly focuses on the SMOS mission, other satellite-based soil moisture products from the existing and future missions such as AMSR-E, ASCAT, and SMAP can profit from the established network (for references see the individual networks in Sect. 4). However, the intention of the ISMN is to go beyond the role of satellite validation resource and to serve other scientific and applicationoriented communities as well, such as hydrological modeling, numerical weather forecasting, and water management. To fulfill this task, the ISMN stores not only surface soil moisture but also soil water content of the deeper layers and relevant hydrometeorological variables such as precipitation and temperature of the air and soil. In addition, to better serve time critical applications (ranging from several hours to a few days), the ISMN has been structured in a way that enables processing incoming soil moisture measurements on a fully automated basis. The automated daily update of data from the FMI network shows that a NRT assimilation and redistribution of data is possible. Nevertheless, prerequisite for the added value of such a mode is the presence of operational measurement and processing chains on the part of the data providers in order to guarantee timely data delivery to the ISMN.

\subsection{Considerations on data representativeness and quality}

The appropriateness of one or more soil moisture datasets from the ISMN for a specific application strongly depends on the spatial and temporal scales of the in-situ measurements and of the process that the user wishes to describe. For example, if the aim is to validate satellite-derived surface soil moisture, the user should be aware that these products contain information only about the upper few millimeters to centimeters of the soil column, whereas a technique based on cosmic-ray neutrons provides information up to a depth of $\sim 70 \mathrm{~cm}$. On the other hand, the latter provides estimates 
that are spatially more consistent than single electromagnetic devices or gravimetric measurements.

Apart from the choice of the measurement technique itself, also its employment has a strong impact on what is exactly observed. The in-situ measurements are influenced by several factors including:

- Installation depth of the sensor.

- Placement of the sensor, e.g., is sensor positioned horizontally or vertically?

- Is soil moisture measured at a specific depth or integrated over a certain soil depth interval? This is often closely related to the positioning of the instrument.

- Density and geographical distribution of measurements.

- Characterization of the soil, including texture, porosity, and organic matter content.

- Calibration of the sensor

Ideally, all these factors should be accounted for when harmonizing in situ soil measurements from different sites, so that observed variations are related only to real differences in soil moisture. However, such a harmonization of data would go beyond the current objective of the ISMN.

The choice of the measurement technique may also have a strong impact on the data quality. In Sect. 2.2 and several advantages and disadvantages of the different techniques were highlighted while the relative performance of various sensors has been extensively documented in literature (Baumhardt et al., 2000; Walker et al., 2004; Czarnomski et al., 2005; Mittelbach et al., 2011). Even if TDR sensors nowadays are often considered as benchmark for operational field monitoring of soil moisture, other, less expensive systems may in many situations show comparable performance (e.g. Czarnomski et al., 2005) and therefore should not be excluded on beforehand from data analysis.

The relative accuracy and precision of stations may differ from site to site (even when employing similar instruments) and can shift over time due to sensor degradation or external disturbances. Not considering these differences in further usage of the data may falsely affect results obtained and conclusions drawn by a study. Therefore, adequate quality characterization of the individual networks and stations is highly desired. As the current quality control procedure is only able to detect evident outliers but does not give us any information about subtle differences between stations, future efforts will primarily focus on improved quality control. This will be done at the level of individual measurement values as well as at the station and network level.

\subsection{Utilization strategies for ISMN datasets}

Evaluating satellite- and model-derived soil moisture retrievals with in situ soil moisture measurements is commonly based on the root-mean-square metric (Jackson et al., 2010). However, to use in situ soil moisture measurements from the ISMN in satellite and land surface model validation and calibration, the user should be aware of the systematic differences that may exist between in situ measurements and soil moisture estimates from models and satellite observations (Entekhabi et al., 2010b). Even though the ISMN provides soil moisture measurements in the same volumetric unit that is returned by most satellite products and models, biases and differences in the dynamic range may exist between the datasets, e.g., by assumptions and generalizations made within the retrieval concept, scaling issues, or due to the different soil layers or soil depths considered. Thus, other metrics, such as the Pearson or Spearman correlation coefficient, often provide valuable and complementary information on the performance (Entekhabi et al., 2010b).

To combine in situ soil moisture measurements with satellite retrievals and a first guess predicted by a land surface model, e.g., in the framework of data assimilation, it is often necessary to minimize systematic differences between the individual datasets (e.g. Drusch, 2007). These correction methods include standard rescaling techniques, e.g. based on simple statistic descriptors of both datasets such as minimum, maximum, mean, and variance (Dorigo et al., 2010; Miralles et al., 2010), linear regression (Scipal et al., 2008), or CDFmatching (Drusch et al., 2005; Liu et al., 2011). Other studies propose the use of exponential filters or land surface models to find a robust relationship between the soil moisture dynamics observed at different observation depths and in different observation spaces (Wagner et al., 1999; Sabater et al., 2007; Albergel et al., 2008).

\subsection{Additional science benefits of the ISMN}

Since for the first time a globally harmonized soil moisture dataset is available, the ISMN may help to find comprehensive answers to fundamental science questions regarding soil moisture and its role in the integrated water cycle, such as:

- Can we refine our understanding of the memory of soil moisture (e.g., Entin et al., 2000)? How does it depend on climate variability, climate persistence and soil hydraulic properties? How do vegetation characteristics affect this memory?

- How is surface soil moisture dynamics linked with that in the subsurface profile? How does soil moisture at the surface and below the surface respond to precipitation events and drydowns? 
- Can long-term trends and changes in the frequencies of extremes that have been regionally observed in regional in situ observations (e.g., Robock et al., 2005) be extrapolated to the global scale?

- What are the functional relationships between soil moisture and evaporation (e.g. Jung et al., 2010)? How does it depend on vegetation, soil type and structure?

In addition, existing knowledge on the temporal stability and spatial correlation of soil moisture (e.g. Vachaud et al., 1985; Martínez-Fernández and Ceballos, 2005; Cosh et al., 2008), can now be strengthened with global evidence. Moreover, there is a proven strong relationship between soil moisture and the biogeochemical cycles (e.g. Ciais et al., 2005) while, at the same time, our knowledge on how this interaction exactly takes place is still very limited (van der Molen et al., 2011). The ISMN may help to gain further inside in this process.

\section{Conclusions and outlook}

With the establishment of the ISMN data hosting center presented in this paper, a first important step has been taken toward a global soil moisture observing system. Although soil moisture is now recognized as an essential climate variable by GCOS, the growth and continuity of this effort will depend upon the commitment of financial support and the cooperation of data providers on a long-term basis. To reach the goal of a fully integrated global soil moisture observing system it will be necessary to establish, expand and improve current soil moisture observations, both in situ and remotely sensed. The in situ efforts should focus on:

- Developing a coordinated plan for soil moisture networks at both the national and international levels.

- Designing a supersite program, approximately satellite footprint size regions with high density measurements, needed to provide the comprehensive datasets required for satellite sensor evaluation and calibration, and to provide a basis for developing soil wetness algorithms for satellite measurements and the evaluation of climate model outputs. For example, we expect the newly established National Ecological Observatory Network (NEON) in the US and the densely sampled watershed validation networks operated by USDA, to help serve as a model for such efforts.

- Enhancing consistency and standardization of measurements, data, and metadata.

- Striving for data continuity and automation.

- Advancing data exchange.
The positive and vital contributions of international organizations such as WCRP, GEWEX and GEO, the support of Space Agencies, and the voluntary efforts of numerous individual scientists contributing to the ISMN have raised the confidence that the consciousness and willingness to realize such an integrated soil moisture observing system are ubiquitous.

Finally, we would like to emphasize that the ISMN is a growing entity animated by the scientific community itself. We therefore solicit users to download, use, and give feedback on the datasets currently contained in the database, and invite potential networks to enrich the collection by sharing their data with the ISMN. As was demonstrated by the success the Global Soil Moisture Data Bank (Robock et al., 2000), the benefit of sharing soil moisture data free of cost with the scientific community is valuable not only for data users but also for the networks. Networks may become embedded as key networks in international calibration and validation activities or climate monitoring programs, e.g. like happened to the flux tower sites participating to FLUXNET (Baldocchi et al., 2001) or the stations participating to the Baseline Surface Radiation Network (Ohmura et al., 1998). This in turn may lead to vast international scientific recognition and pave the way for access to extended funding resources.

Acknowledgements. We greatly thank all data providers that kindly shared their data with the ISMN: Thierry Pellarin (AMMA), Loredana Marsica and Luca Brocca (CALABRIA), Matteo Gentilella and Giovanni Battista Chirico (CAMPANIA), Konstantin Vinnikov and Thomas Collow (CHINA, IOWA, MONGOLIA, RUSWET-AGRO, RUSWET-GRASS, and RUSWET-VALDAI), Luca Brocca (CNR-IRPI), Matias Takala, Hanne Suokanerva, Jouni Pullianen, Jarkko Koskinen (FMI), Bob Scott (ICN), Udo Rummel (MOL-RAO), Jeffrey Walker and Christoph Rüdiger (OZNET), José Martínez Fernández (REMEDHUS), Jean-Christophe Calvet (SMOSMANIA), Bogusaw Usowicz, Jerzy Usowicz, and Wojciech Marczewski (SWEX_Poland), Florian Schlenz, Johanna dall'Amico, Alexander Loew, Wolfram Mauser (UDC_SMOS), Vittorio Marletto and Marco Bittelli (UMSUOL). Without their valuable contributions this initiative would not have been possible in the first place. The ISMN has been funded through the SMOS Soil Moisture Network Study (ESA ESTEC Contract No. 22954/09) and the SMOS Soil Moisture Network Study Operational Phase (ESA ESTEC Contract No. 4000102722/10). Alan Robock is supported by NASA grant NNX09AJ99G. We greatly acknowledge the editor and the reviewers whose valuable comments and remarks substantially helped to improve the manuscript.

Edited by: F. Pappenberger 


\section{References}

Albergel, C., Rüdiger, C., Pellarin, T., Calvet, J.-C., Fritz, N., Froissard, F., Suquia, D., Petitpa, A., Piguet, B., and Martin, E.: From near-surface to root-zone soil moisture using an exponential filter: an assessment of the method based on in-situ observations and model simulations, Hydrol. Earth Syst. Sci., 12, 1323-1337, doi:10.5194/hess-12-1323-2008, 2008.

Albergel, C., Rüdiger, C., Carrer, D., Calvet, J.-C., Fritz, N., Naeimi, V., Bartalis, Z., and Hasenauer, S.: An evaluation of ASCAT surface soil moisture products with in-situ observations in Southwestern France, Hydrol. Earth Syst. Sci., 13, 115-124, doi:10.5194/hess-13-115-2009, 2009.

Albergel, C., Calvet, J.-C., de Rosnay, P., Balsamo, G., Wagner, W., Hasenauer, S., Naeimi, V., Martin, E., Bazile, E., Bouyssel, F., and Mahfouf, J.-F.: Cross-evaluation of modelled and remotely sensed surface soil moisture with in situ data in southwestern France, Hydrol. Earth Syst. Sci., 14, 2177-2191, doi:10.5194/hess-14-2177-2010, 2010.

Baldocchi, D., Falge, E., Gu, L., Olson, R., Hollinger, D., Running, S., Anthoni, P., Bernhofer, C., Davis, K., Evans, R., Fuentes, J., Goldstein, A., Katul, G., Law, B., Lee, X., Malhi, Y., Meyers, T., Munger, W., Oechel, W., Paw, K. T., Pilegaard, K., Schmid, H. P., Valentini, R., Verma, S., Vesala, T., Wilson, K., and Wofsy, S.: FLUXNET: A New Tool to Study the Temporal and Spatial Variability of Ecosystem-Scale Carbon Dioxide, Water Vapor, and Energy Flux Densities, B. Am. Meteorol. Soc., 82, 24152434, doi:10.1175/1520-0477, 2001.

Balsamo, G., Viterbo, P., Beljaars, A., van den Hurk, B., Hirschi, M., Betts, A. K., and Scipal, K.: A Revised Hydrology for the ECMWF Model: Verification from Field Site to Terrestrial Water Storage and Impact in the Integrated Forecast System, J. Hydromet., 10, 623-643, doi:10.1175/2008jhm1068.1, 2009.

Baumhardt, R. L., Lascano, R. J., and Evett, S. R.: Soil material, temperature, and salinity effects on calibration of multisensor capacitance probes, Soil Sci. Soc. Am. J., 64, 1940-1946, 2000.

Beyrich, F. and Adam, W. K.: Site and Data Report for the Lindenberg Reference Site in CEOP - Phase I, German Weather Service, Offenbach am Main, 55, 2007.

Beyrich, F., Leps, J. P., Mauder, M., Bange, J., Foken, T., Huneke, S., Lohse, H., Lüdi, A., Meijninger, W. M. L., Mironov, D., Weisensee, U., and Zittel, P.: Area-averaged surface fluxes over the litfass region based on eddy-covariance measurements, Boundary-layer Met., 121, 33-65, 2006.

Bogena, H. R., Huisman, J. A., Oberdorster, C., and Vereecken, H.: Evaluation of a low-cost soil water content sensor for wireless network applications, J. Hydrol., 344, 32-42, 10.1016/j.jhydrol.2007.06.032, 2007.

Braud, I., Noilhan, J., Bessemoulin, P., Mascart, P., Haverkamp, R., and Vauclin, M.: Bare-ground surface heat and water exchanges under dry conditions: Observations and parameterization, Boundary-layer Met., 66, 173-200, 1993.

Brocca, L., Morbidelli, R., Melone, F., and Moramarco, T.: Soil moisture spatial variability in experimental areas of central Italy, J. Hydrol., 333, 356-373, 2007.

Brocca, L., Melone, F., and Moramarco, T.: On the estimation of antecedent wetness conditions in rainfall-runoff modelling, Hydrol. Process., 22, 629-642, 2008.

Brocca, L., Melone, F., Moramarco, T., and Morbidelli, R.: Antecedent wetness conditions based on ERS scatterometer data, J.
Hydrol., 364, 73-87, 2009.

Brocca, L., Melone, F., Moramarco, T., and Morbidelli, R.: Spatial-temporal variability of soil moisture and its estimation across scales, Wat. Resour. Res., 46, W02516, doi:10.1029/2009wr008016, 2010a.

Brocca, L., Melone, F., Moramarco, T., Wagner, W., and Hasenauer, S.: ASCAT soil wetness index validation through in situ and modeled soil moisture data in central Italy, Remote Sens. Environ., 114, 2745-2755, doi:10.1016/j.rse.2010.06.009, 2010 b.

Brocca, L., Hasenauer, S., Lacava, T., Melone, F., Moramarco, T., Wagner, W., Dorigo, W., Matgen, P., Martínez-Fernández, J., llorens, P., Latron, J., Martin, C., and Bittelli, M.: Soil moisture estimation through ASCAT and AMSR-E sensors: An intercoparison and validation study across Europe, Remote Sensing Envir., in review, 2011.

Calvet, J. C., Fritz, N., Froissard, F., Suquia, D., Petitpa, A., and Piguet, B.: In situ soil moisture observations for the CAL/VAL of SMOS: The SMOSMANIA network, Int. Geosci. Remote Se., IGARSS, Barcelona, Spain, 1196-1199, 2008.

Cappelaere, B., Descroix, L., Lebel, T., Boulain, N., Ramier, D., Laurent, J. P., Favreau, G., Boubkraoui, S., Boucher, M., Bouzou Moussa, I., Chaffard, V., Hiernaux, P., Issoufou, H. B. A., Le Breton, E., Mamadou, I., Nazoumou, Y., Oi, M., Ottlé, C., and Quantin, G.: The AMMA-CATCH experiment in the cultivated Sahelian area of south-west Niger - Investigating water cycle response to a fluctuating climate and changing environment, J. Hydrol., 375, 34-51, 2009.

Ceballos, A., Scipal, K., Wagner, W., and Martinez-Fernandez, J.: Validation of ERS scatterometer-derived soil moisture data in the central part of the Duero Basin, Spain, Hydrol. Process., 19, 1549-1566, doi:10.1002/Hyp.5585, 2005.

Chen, X. and $\mathrm{Hu}, \mathrm{Q} .:$ Groundwater influences on soil moisture and surface evaporation, J. Hydrol., 297, 285-300, 2004.

Ciais, P., Reichstein, M., Viovy, N., Granier, A., Ogée, J., Allard, V., Aubinet, M., Buchmann, N., Bernhofer, C., Carrara, A., Chevallier, F., De Noblet, N., Friend, A. D., Friedlingstein, P., Grünwald, T., Heinesch, B., Keronen, P., Knohl, A., Krinner, G., Loustau, D., Manca, G., Matteucci, G., Miglietta, F., Ourcival, J. M., Papale, D., Pilegaard, K., Rambal, S., Seufert, G., Soussana, J. F., Sanz, M. J., Schulze, E. D., Vesala, T., and Valentini, R.: Europe-wide reduction in primary productivity caused by the heat and drought in 2003, Nature, 437, 529-533, 2005.

Cosh, M. H., Jackson, T. J., Moran, S., and Bindlish, R.: Temporal persistence and stability of surface soil moisture in a semi-arid watershed, Remote Sens. Environ., 112, 304-313, 2008.

Czarnomski, N. M., Moore, G. W., Pypker, T. G., Licata, J., and Bond, B. J.: Precision and accuracy of three alternative instruments for measuring soil water content in two forest soils of the Pacific Northwest, Can. J. For. Res., 35, 1867-1876, 2005.

Dai, A., Trenberth, K. E., and Qian, T.: A global dataset of Palmer Drought Severity Index for 1870-2002: Relationship with soil moisture and effects of surface warming, J. Hydromet., 5, 11171130, 2004.

de Rosnay, P., Gruhier, C., Timouk, F., Baup, F., Mougin, E., Hiernaux, P., Kergoat, L., and LeDantec, V.: Multi-scale soil moisture measurements at the Gourma meso-scale site in Mali, J. Hydrol., 375, 241-252, 2009.

Desilets, D., Zreda, M., and Ferré, T. P. A.: Nature's neutron probe: Land surface hydrology at an elusive scale with cosmic rays, 
Wat. Resour. Res., 46, W11505, doi:10.1029/2009WR008726, 2010.

Dirmeyer, P. A.: Using a global soil wetness dataset to improve seasonal climate simulation, J. Climate, 13, 2900-2922, 2000.

Dirmeyer, P. A., Dolman, A. J., and Sato, N.: The Pilot Phase of the Global Soil Wetness Project, B. Am. Meteorol. Soc., 80, 851878, 1999.

Dirmeyer, P. A., Gao, X., Zhao, M., Guo, Z., Oki, T., and Hanasaki, N.: GSWP-2: Multimodel analysis and implications for our perception of the land surface, B. Am. Met. Soc., 87, 1381-1397, 2006.

Dorigo, W. A., Scipal, K., Parinussa, R. M., Liu, Y. Y., Wagner, W., de Jeu, R. A. M., and Naeimi, V.: Error characterisation of global active and passive microwave soil moisture datasets, Hydrol. Earth Syst. Sci., 14, 2605-2616, doi:10.5194/hess-142605-2010, 2010.

Dorigo, W. A., Van Oevelen, P., Wagner, W., Drusch, M., Mecklenburg, S., Robock, A., and Jackson, T.: A New International Network for in Situ Soil Moisture Data, EOS, Transcations, American Geophysical Union, 92, 141-142, 2011.

Draper, C. S., Walker, J. P., Steinle, P. J., de Jeu, R. A. M., and Holmes, T. R. H.: An evaluation of AMSR-E derived soil moisture over Australia, Remote Sensing Envir., 113, 703-710, doi:10.1016/j.rse.2008.11.011, 2009.

Drusch, M.: Initializing numerical weather prediction models with satellite-derived surface soil moisture: Data assimilation experiments with ECMWF's integrated forecast system and the TMI soil moisture data set, J. Geophys. Res.-Atmos., 112, D03102 10.1029/2006JD007478, 2007.

Drusch, M. and Viterbo, P.: Assimilation of screen-level variables in ECMWF's integrated forecast system: A study on the impact on the forecast quality and analyzed soil moisture, Mon. Weather Rev., 135, 300-314, 2007.

Drusch, M., Wood, E. F., and Gao, H.: Observation operators for the direct assimilation of TRMM microwave imager retrieved soil moisture, Geophys. Res. Lett., 32, L15403, doi:10.1029/2005GL023623, 2005.

Entekhabi, D., Njoku, E. G., O’Neill, P. E., Kellogg, K. H., Crow, W. T., Edelstein, W. N., Entin, J. K., Goodman, S. D., Jackson, T. J., Johnson, J., Kimball, J., Piepmeier, J. R., Koster, R. D., Martin, N., McDonald, K. C., Moghaddam, M., Moran, S., Reichle, R., Shi, J. C., Spencer, M. W., Thurman, S. W., Tsang, L., and Van Zyl, J.: The soil moisture active passive (SMAP) mission, P. IEEE, 98, 704-716, 2010a.

Entekhabi, D., Reichle, R. H., Koster, R. D., and Crow, W. T.: Performance Metrics for Soil Moisture Retrievals and Application Requirements, J. Hydromet., 11, 832-840, doi:10.1175/2010JHM1223.1, 2010 b.

Entin, J. K., Robock, A., Vinnikov, K. Y., Hollinger, S. E., Liu, S., and Namkhai, A.: Temporal and spatial scales of observed soil moisture variations in the extratropics, J. Geophys. Res.-Atmos., 105, 11865-11877, 2000.

Famiglietti, J. S., Devereaux, J. A., Laymon, C. A., Tsegaye, T., Houser, P. R., Jackson, T. J., Graham, S. T., Rodell, M., and Van Oevelen, P. J.: Ground-based investigation of soil moisture variability within remote sensing footprints during the Southern Great Plains 1997 (SGP97) Hydrology Experiment, Wat. Resour. Res., 35, 1839-1851, 1999.

FAO/IIASA/ISRIC/ISS-CAS/JRC: Harmonized World Soil
Database (version 1.1). FAO, Rome, Italy and IIASA, Laxenburg, Austria., 2009.

Findell, K. L. and Eltahir, E. A. B.: An analysis of the soil moisturerainfall feedback, based on direct observations from Illinois, Wat Resour. Res., 33, 725-735, 1997.

Fredlund, D. G. and Rahardjo, H.: Soil mechanics for unsaturated soil., John Wiley and Sons, New York, 1993.

Grabs, W. and Thomas, A. R.: Report of the GCOS/GTOS/HWRP Expert Meeting on the Implementation of a Global Terrestrial Network - Hydrology (GTN-H), WMO/TD No. 1099, 2002.

Gruhier, C., de Rosnay, P., Kerr, Y., Mougin, E., Ceschia, E., Calvet, J. C., and Richaume, P.: Evaluation of AMSR-E soil moisture product based on ground measurements over temperate and semi-arid regions, Geophys. Res. Lett., 35, L10405, doi:10.1029/2008GL033330, 2008.

Gruhier, C., de Rosnay, P., Hasenauer, S., Holmes, T., de Jeu, R., Kerr, Y., Mougin, E., Njoku, E., Timouk, F., Wagner, W., and Zribi, M.: Soil moisture active and passive microwave products: intercomparison and evaluation over a Sahelian site, Hydrol. Earth Syst. Sci., 14, 141-156, doi:10.5194/hess-14-1412010, 2010.

Heret, C., Tittebrand, A., and Berger, F. H.: Latent heat fluxes simulated with a non-hydrostatic weather forecast model using actual surface properties from measurements and remote sensing, Boundary-layer Met., 121, 175-194, 2006.

Hillel, D.: Environmental Soil Physics, Academic Press, San Diego, 771 pp., 1998.

Hollinger, S. E. and Isard, S. A.: A soil moisture climatology of Illinois, J. Climate, 7, 822-833, 1994.

Huang, J., Van Den Dool, H. M., and Georgakakos, K. P.: Analysis of model-calculated soil moisture over the United States (19311993) and applications to long-range temperature forecasts, J. Climate, 9, 1350-1362, 1996.

Jackson, T., Entekhabi, D., Van Oevelen, P. J., and Kerr, Y.: Towards integrated global soil moisture observations, GEWEX News, 15, 8-9, 2005.

Jackson, T. J.: III. Measuring surface soil moisture using passive microwave remote sensing, Hydrol. Process., 7, 139-152, 1993.

Jackson, T. J., Gasiewski, A. J., Oldak, A., Klein, M., Njoku, E. G., Yevgrafov, A., Christiani, S., and Bindlish, R.: Soil moisture retrieval using the $\mathrm{C}$-band polarimetric scanning radiometer during the Southern Great Plains 1999 Experiment, IEEE T. Geosci. Remote, 40, 2151-2161, 2002.

Jackson, T. J., Cosh, M. H., Bindlish, R., Starks, P. J., Bosch, D. D., Seyfried, M., Goodrich, D. C., Moran, M. S., and Du, J.: Validation of Advanced Microwave Scanning Radiometer Soil Moisture Products, IEEE T. Geosci. Remote, 48, 4256-4272, doi:10.1109/TGRS.2010.2051035, 2010.

Jung, M., Reichstein, M., Ciais, P., Seneviratne, S. I., Sheffield, J., Goulden, M. L., Bonan, G., Cescatti, A., Chen, J. Q., de Jeu, R., Dolman, A. J., Eugster, W., Gerten, D., Gianelle, D., Gobron, N., Heinke, J., Kimball, J., Law, B. E., Montagnani, L., Mu, Q. Z., Mueller, B., Oleson, K., Papale, D., Richardson, A. D., Roupsard, O., Running, S., Tomelleri, E., Viovy, N., Weber, U., Williams, C., Wood, E., Zaehle, S., and Zhang, K.: Recent decline in the global land evapotranspiration trend due to limited moisture supply, Nature, 467, 951-954, doi:10.1038/nature09396, 2010.

Kerr, Y. H., Waldteufel, P., Wigneron, J. P., Martinuzzi, J. M., Font, 
J., and Berger, M.: Soil moisture retrieval from space: The Soil Moisture and Ocean Salinity (SMOS) mission, IEEE T. Geosci. Remote, 39, 1729-1735, 2001.

Koike, T., Nakamura, Y., Kaihotsu, I., Davva, N., Matsuura, N., Tamagawa, K., and Fujii, H.: Development of an Advanced Microwave Scanning Radiometer (AMSR-E) Algorithm of Soil Moisture and Vegetation Water Content, Annual J. Hydraul. Eng., JSCE, 48, 217-222, 2004.

Lebel, T., Cappelaere, B., Galle, S., Hanan, N., Kergoat, L., Levis, S., Vieux, B., Descroix, L., Gosset, M., Mougin, E., Peugeot, C., and Seguis, L.: AMMA-CATCH studies in the Sahelian region of West-Africa: An overview, J. Hydrol., 375, 3-13, 2009.

Li, L., Gaiser, P. W., Gao, B. C., Bevilacqua, R. M., Jackson, T. J., Njoku, E. G., Rüdiger, C., Calvet, J. C., and Bindlish, R.: WindSat global soil moisture retrieval and validation, IEEE T. Geosci. Remote, 48, 2224-2241, 2010.

Liu, Y. Y., Parinussa, R. M., Dorigo, W. A., De Jeu, R. A. M., Wagner, W., van Dijk, A. I. J. M., McCabe, M. F., and Evans, J. P.: Developing an improved soil moisture dataset by blending passive and active microwave satellite-based retrievals, Hydrol. Earth Syst. Sci., 15, 425-436, doi:10.5194/hess-15-425-2011, 2011.

Loew, A. and Schlenz, F.: A dynamic approach for evaluating coarse scale satellite soil moisture products, Hydrol. Earth Syst. Sci., 15, 75-90, doi:10.5194/hess-15-75-2011, 2011.

Loew, A., Dall'Amico, J. T., Schlenz, F., and Mauser, W.: The Upper Danube soil moisture validation site: measurements and activities, Earth Observation and Water Cycle Conference, Frascati (Rome), 18-20 November 2009, ESA Special Publications, SP674, 2009.

Luo, L., Robock, A., Vinnikov, K. Y., Schlosser, C. A., Slater, A. G., Boone, A., Braden, H., Cox, P., de Rosnay, P., Dickinson, R. E., Dai, Y., Duan, Q., Etchevers, P., Henderson-Sellers, A., Gedney, N., Gusev, Y. M., Habets, F., Kim, J., Kowalczyk, E., Mitchell, K., Nasonova, O. N., Noilhan, J., Pitman, A. J., Schaake, J., Shmakin, A. B., Smirnova, T. G., Wetzel, P., Xue, Y., Yang, Z. L., and Zeng, Q. C.: Effects of frozen soil on soil temperature, spring infiltration, and runoff: Results from the PILPS 2(d) experiment at Valdai, Russia, J. Hydromet., 4, 334-351, 2003.

Mahfouf, J. F. and Noilhan, J.: Comparative study of various formulations of evaporation from bare soil using in situ data, J. Appl. Meteorol., 30, 1354-1365, 1991.

Marczewski, W., Slominski, J., Slominska, E., Usowicz, B., Usowicz, J., Romanov, S., Maryskevych, O., Nastula, J., and Zawadzki, J.: Strategies for validating and directions for employing SMOS data, in the Cal-Val project SWEX (3275) for wetlands, Hydrol. Earth Syst. Sci. Discuss., 7, 7007-7057, doi:10.5194/hessd-7-7007-2010, 2010.

Martínez-Fernández, J., and Ceballos, A.: Temporal Stability of Soil Moisture in a Large-Field Experiment in Spain, Soil Sci. Soc. Am. J., 67, 1647-1656, 2003.

Martínez-Fernández, J. and Ceballos, A.: Mean soil moisture estimation using temporal stability analysis, J. Hydrol., 312, 28-38, 2005.

Maurer, E. P., Wood, A. W., Adam, J. C., Lettenmaier, D. P., and Nijssen, B.: A long-term hydrologically based dataset of land surface fluxes and states for the conterminous United States, J. Climate, 15, 3237-3251, 2002.

Miralles, D. G., Crow, W. T., and Cosh, M. H.: Estimating spa- tial sampling errors in coarse-scale soil moisture estimates derived from point-scale observations, J. Hydromet., 11, 14231429, doi:10.1175/2010JHM1285.1, 2010.

Mittelbach, H., Casini, F., Lehner, I., Teuling, A. J., and Seneviratne, S. I.: Soil moisture monitoring for climate research: Evaluation of a low-cost sensor in the framework of the Swiss soil moisture experiment (SwissSMEX) campaign, J. Geophys. Res.Atmos., 116, D05111, doi:10.1029/2010JD014907, 2011.

Mougin, E., Hiernaux, P., Kergoat, L., Grippa, M., de Rosnay, P., Timouk, F., Le Dantec, V., Demarez, V., Lavenu, F., Arjounin, M., Lebel, T., Soumaguel, N., Ceschia, E., Mougenot, B., Baup, F., Frappart, F., Frison, P. L., Gardelle, J., Gruhier, C., Jarlan, L., Mangiarotti, S., Sanou, B., Tracol, Y., Guichard, F., Trichon, V., Diarra, L., Soumaré, A., Koité, M., Dembélé, F., Lloyd, C., Hanan, N. P., Damesin, C., Delon, C., Serça, D., Galy-Lacaux, C., Seghieri, J., Becerra, S., Dia, H., Gangneron, F., and Mazzega, P.: The AMMA-CATCH Gourma observatory site in Mali: Relating climatic variations to changes in vegetation, surface hydrology, fluxes and natural resources, J. Hydrol., 375, 14-33, 2009.

Naeimi, V., Scipal, K., Bartalis, Z., Hasenauer, S., and Wagner, W.: An Improved Soil Moisture Retrieval Algorithm for ERS and METOP Scatterometer Observations, IEEE T. Geosci. Remote, 47, 1999-2013, doi:10.1109/Tgrs.2009.2011617, 2009.

Njoku, E. G., Jackson, T. J., Lakshmi, V., Chan, T. K., and Nghiem, S. V.: Soil moisture retrieval from AMSR-E, IEEE T. Geosci. Remote, 41, 215-229, 2003.

Ohmura, A., Dutton, E. G., Forgan, B., Fröhlich, C., Gilgen, H., Hegner, H., Heimo, A., König-Langlo, G., McArthur, B., Müller, G., Philipona, R., Pinker, R., Whitlock, C. H., Dehne, K., and Wild, M.: Baseline Surface Radiation Network (BSRN/WCRP): New Precision Radiometry for Climate Research, B. Am. Meteorol. Soc., 79, 2115-2136, 1998.

Oleson, K. W., Niu, G. Y., Yang, Z. L., Lawrence, D. M., Thornton, P. E., Lawrence, P. J., Stöckli, R., Dickinson, R. E., Bonan, G. B., Levis, S., Dai, A., and Qian, T.: Improvements to the community land model and their impact on the hydrological cycle, J. Geophys. Res.-Biogeo., 113, G01021, doi:10.1029/2007JG000563, 2008.

Owe, M., De Jeu, R., and Walker, J.: A methodology for surface soil moisture and vegetation optical depth retrieval using the microwave polarization difference index, IEEE T. Geosci. Remote, 39, 1643-1654, 2001.

Owe, M., de Jeu, R., and Holmes, T.: Multisensor historical climatology of satellite-derived global land surface moisture, J. Geophys. Res.-Earth., 113, F01002, doi:10.1029/2007jf000769, 2008.

Parinussa, R., Meesters, A. G. C. A., Liu, Y. Y., Dorigo, W., Wagner, W., and De Jeu, R. A. M.: An analytical solution to estimate the error structure of a global soil moisture data set, IEEE Geosci. Remote Sens., 8, 779-783, 2011.

Peck, E. L. and Hope, A. S.: Spatial patterns of soil moisture for the FIFE study area derived from remotely sensed and ground data, J. Geophys. Res., 100, 25463-425468, 1995.

Pellarin, T., Laurent, J. P., Cappelaere, B., Decharme, B., Descroix, L., and Ramier, D.: Hydrological modelling and associated microwave emission of a semi-arid region in South-western Niger, J. Hydrol., 375, 262-272, 2009a.

Pellarin, T., Tran, T., Cohard, J.-M., Galle, S., Laurent, J.-P., de 
Rosnay, P., and Vischel, T.: Soil moisture mapping over West Africa with a 30-min temporal resolution using AMSR-E observations and a satellite-based rainfall product, Hydrol. Earth Syst. Sci., 13, 1887-1896, doi:10.5194/hess-13-1887-2009, $2009 \mathrm{~b}$.

Prince, S. D., Kerr, Y. H., Goutorbe, J. P., Lebel, T., Tinga, A., Bessemoulin, P., Brouwer, J., Dolman, A. J., Engman, E. T., Gash, J. H., Hoepffner, M., Kabat, P., Monteny, B., Said, F., Sellers, P., and Wallace, J.: Geographical, biological and remote sensing aspects of the hydrologic atmospheric pilot experiment in the Sahel (HAPEX-Sahel), Remote Sens. Environ., 51, 215234, 1995.

Pulliainen, J. T., Heiska, K., Hyyppa, J., and Hallikainen, M. T.: Backscattering properties of boreal forests at the C-and X-bands, IEEE T. Geosci. Remote., 32, 1041-1050, 1994.

Rautiainen, K., Lemmetyiner, J., Pullianen, J., Vehviläinen, J., Drusch, M., Kontu, A., Kainulainen, J., and Seppänen, J.: L-Band Radiometer Observations of Soil Processes at Boreal and SubArctic Environments, IEEE T. Geosci. Remote., in review, 2011.

Reichle, R. H., Koster, R. D., Dong, J., and Berg, A. A.: Global soil moisture from satellite observations, land surface models, and ground data: Implications for data assimilation, J. Hydrometeorol., 5, 430-442, 2004.

Richter, H., Western, A. W., and Chiew, F. H. S.: The effect of soil and vegetation parameters in the ECMWF land surface scheme, J. Hydrometeorol., 5, 1131-1146, 2004.

Robinson, D. A., Campbell, C. S., Hopmans, J. W., Hornbuckle, B. K., Jones, S. B., Knight, R., Ogden, F., Selker, J., and Wendroth, O.: Soil moisture measurement for ecological and hydrological watershed-scale observatories: A review, Vadose Zone J., 7, 358-389, 2008.

Robock, A., Vinnikov, K. Y., Schlosser, C. A., Speranskaya, N. A., and Yongkang, X.: Use of midlatitude soil moisture and meteorological observations to validate soil moisture simulations with biosphere and bucket models, J. Climate, 8, 15-35, 1995.

Robock, A., Schlosser, C. A., Vinnikov, K. Y., Speranskaya, N. A., Entin, J. K., and Qiu, S.: Evaluation of the AMIP soil moisture simulations, Global Planet. Change, 19, 181-208, 1998.

Robock, A., Vinnikov, K. Y., Srinivasan, G., Entin, J. K., Hollinger, S. E., Speranskaya, N. A., Liu, S., and Namkhai, A.: The Global Soil Moisture Data Bank, B. Am. Meteorol. Soc., 81, 12811299, 2000.

Robock, A., Mu, M., Vinnikov, K., Trofimova, I. V., and Adamenko, T. I.: Forty-five years of observed soil moisture in the Ukraine: No summer desiccation (yet), Geophys. Res. Lett., 32, 1-5, doi:10.1029/2004GL021914, 2005.

Rodell, M., Houser, P. R., Jambor, U., Gottschalck, J., Mitchell, K., Meng, C. J., Arsenault, K., Cosgrove, B., Radakovich, J., Bosilovich, M., Entin, J. K., Walker, J. P., Lohmann, D., and Toll, D.: The Global Land Data Assimilation System, B. Am. Meteorol. Soc., 85, 381-394, 2004.

Rüdiger, C., Hancock, G., Hemakumara, H. M., Jacobs, B., Kalma, J. D., Martinez, C., Thyer, M., Walker, J. P., Wells, T., and Willgoose, G. R.: Goulburn River experimental catchment data set, Wat. Resour. Res., 43, W10403, doi:10.1029/2006WR005837, 2007.

Sabater, J. M., Jarlan, L., Calvet, J. C., Bouyssel, F., and De Rosnay, P.: From near-surface to root-zone soil moisture using different assimilation techniques, J. Hydrometeorol., 8, 194-206, 2007.

Saxton, K. E. and Rawls, W. J.: Soil water characteristic estimates by texture and organic matter for hydrologic solutions, Soil Sci. Soc. Am. J., 70, 1569-1578, doi:10.2136/sssaj2005.0117, 2006.

Schlosser, C. A., Slater, A. G., Robock, A., Pitman, A. J., Vinnikov, K. Y., Henderson-Sellers, A., Speranskaya, N. A., Mitchell, K., Boone, A., Braden, H., Chen, F., Cox, P., De Rosnay, P., Desborough, C. E., Dickenson, R. E., Dai, Y. J., Duan, Q., Entin, J., Etchevers, P., Gedney, N., Gusev, Y. M., Habets, F., Kim, J., Koren, V., Kowalczyk, E., Nasonova, O. N., Noilhan, J., Schaake, J., Shmakin, A. B., Smirnova, T. G., Verseghy, D., Wetzel, P., Xue, Y., and Yang, Z. L.: Simulations of a boreal grassland hydrology at Valdai, Russia: PILPS phase 2(d), Mon. Weather Rev., 128, 301-321, 2000.

Scipal, K., Wagner, W., Trommler, M., and Naumann, K.: The global soil moisture archive 1992-2000 from ERS scatterometer data: First results, IGARSS 2002: IEEE International Geoscience and Remote Sensing Symposium and 24th Canadian Symposium on Remote Sensing, Toronto, Canada, ISI:000179116800457, 1399-1401, 2002.

Scipal, K., Holmes, T., de Jeu, R., Naeimi, V., and Wagner, W.: A possible solution for the problem of estimating the error structure of global soil moisture data sets, Geophys. Res. Lett., 35, L24403, doi:10.1029/2008g1035599, 2008.

Seneviratne, S. I., Corti, T., Davin, E. L., Hirschi, M., Jaeger, E. B., Lehner, I., Orlowsky, B., and Teuling, A. J.: Investigating soil moisture-climate interactions in a changing climate: A review, Earth-Sci. Rev., 99, 125-161, 2010.

Simmons, A., Uppala, S., Dee, D., and Kobayashi, S.: ERAInterim: New ECMWF reanalysis products from 1989 onwards, ECMWF Newsletter, 110, 25-35, 2007.

Slater, A. G., Schlosser, C. A., Desborough, C. E., Pitman, A. J., Henderson-Sellers, A., Robock, A., Vinnikov, K. Y., Mitchell, K., Boone, A., Braden, H., Chen, F., Cox, P. M., De Rosnay, P., Dickinson, R. E., Dai, Y. J., Duan, Q., Entin, J., Etchevers, P., Gedney, N., Gusev, Y. M., Habets, F., Kim, J., Koren, V., Kowalczyk, E. A., Nasonova, O. N., Noilhan, J., Schaake, S., Shmakin, A. B., Smirnova, T. G., Verseghy, D., Wetzel, P., Xue, Y., Yang, Z. L., and Zeng, Q.: The representation of snow in land surface schemes: Results from PILPS 2(d), J. Hydrometeorol., 2, 7-25, 2001.

Uppala, S. M., Kallberg, P. W., Simmons, A. J., Andrae, U., Bechtold, V. D., Fiorino, M., Gibson, J. K., Haseler, J., Hernandez, A., Kelly, G. A., Li, X., Onogi, K., Saarinen, S., Sokka, N., Allan, R. P., Andersson, E., Arpe, K., Balmaseda, M. A., Beljaars, A. C. M., Van De Berg, L., Bidlot, J., Bormann, N., Caires, S., Chevallier, F., Dethof, A., Dragosavac, M., Fisher, M., Fuentes, M., Hagemann, S., Holm, E., Hoskins, B. J., Isaksen, L., Janssen, P., Jenne, R., McNally, A. P., Mahfouf, J. F., Morcrette, J. J., Rayner, N. A., Saunders, R. W., Simon, P., Sterl, A., Trenberth, K. E., Untch, A., Vasiljevic, D., Viterbo, P., and Woollen, J.: The ERA-40 re-analysis, Q. J. Roy. Meteorol. Soc., 131, 2961-3012, doi:10.1256/qj.04.176, 2005.

Vachaud, G., Royer, J. M., and Cooper, J. D.: Comparison of methods of calibration of a neutron probe by gravimetry or neutroncapture model, J. Hydrol., 34, 343-356, 1977.

Vachaud, G., Passerat De Silans, A., Balabanis, P., and Vauclin, M.: Temporal stability of spatially measured soil water probability density function, Soil Sci. Soc. Am. J., 49, 822-828, 1985.

Van De Griend, A. A., Owe, M., Vugts, H. F., and Prince, S. D.: Water and surface energy balance modeling in Botswana, B. Am. 
Meteorol. Soc., 70, 1404-1411, 1989.

van der Molen, M. K., Dolman, A. J., Ciais, P., Eglin, T., Gobron, N., Law, B. E., Meir, P., Peters, W., Phillips, O. L., Reichstein, M., Chen, T., Dekker, S. C., Doubková, M., Friedl, M. A., Jung, M., van den Hurk, B. J. J. M., de Jeu, R. A. M., Kruijt, B., Ohta, T., Rebel, K. T., Plummer, S., Seneviratne, S. I., Sitch, S., Teuling, A. J., van der Werf, G. R., and Wang, G.: Drought and ecosystem carbon cycling, Agr. For. Met., 151(7), 765-773, doi:10.1016/j.agrformet.2011.01.018, 2011.

Vinnikov, K. Y. and Yeserkepova, I. B.: Soil moisture: Empirical data and model results, J. Climate, 4, 66-79, 1991.

Vinnikov, K. Y., Robock, A., Speranskaya, N. A., and Adam Schlosser, C.: Scales of temporal and spatial variability of midlatitude soil moisture, J. Geophys. Res.-Atmos., 101, 7163-7174, 1996.

Vinnikov, K. Y., Robock, A., Qiu, S., and Entin, J. K.: Optimal design of surface networks for observation of soil moisture, J. Geophys. Res.-Atmos., 104, 19743-19749, 1999a.

Vinnikov, K. Y., Robock, A., Qiu, S., Entin, J. K., Owe, M., Choudhury, B. J., Hollinger, S. E., and Njoku, E. G.: Satellite remote sensing of soil moisture in Illinois, United States, J. Geophys. Res.-Atmos., 104, 4145-4168, 1999b.

Wagner, W., Lemoine, G., and Rott, H.: A method for estimating soil moisture from ERS scatterometer and soil data, Remote Sens. Environ., 70, 191-207, 1999.

Wagner, W., Naeimi, V., Scipal, K., de Jeu, R., and MartinezFernandez, J.: Soil moisture from operational meteorological satellites, Hydrogeol. J., 15, 121-131, doi:10.1007/s10040-0060104-6, 2007.

Walker, J. P., Willgoose, G. R., and Kalma, J. D.: In situ measurement of soil moisture: A comparison of techniques, J. Hydrol., 293, 85-99, 2004.
Wang, J. M., Shiue, J., Engman, E., Lawless, P., Schmugge, T., Jackson, T., Gould, W., Fuchs, J., and Calhoon, C.: Remote Measurements of soil moisture by microwave radiometers at BARC test site, TM-80720, NASA GFSC, 113, 1980.

Ward, R. C. and Robinson, M.: Principles of Hydrology, McGrawHill, Maidenhead, 1990.

Wigneron, J. P., Kerr, Y., Waldteufel, P., Saleh, K., Escorihuela, M. J., Richaume, P., Ferrazzoli, P., de Rosnay, P., Gurney, R., Calvet, J. C., Grant, J. P., Guglielmetti, M., Hornbuckle, B., Mätzler, C., Pellarin, T., and Schwank, M.: L-band Microwave Emission of the Biosphere (L-MEB) Model: Description and calibration against experimental data sets over crop fields, Remote Sens. Environ., 107, 639-655, 2007.

WMO8: Guide to Meteorological Instruments and Methods of Observation, 7 ed., Weather-Climate-Water, World Meteorological Organization, Geneva, Switzerland, 681 pp., 2008.

Yang, Z. L., Dickinson, R. E., Robock, A., and Vinnikov, K. Y.: Validation of the snow submodel of the biosphere-atmosphere transfer scheme with Russian snow cover and meteorological observational data, J. Climate, 10, 353-373, 1997.

Young, R., Walker, J., Yeoh, N., Smith, A., Ellett, K., Merlin, O., and Western, A.: Soil moisture and meteorological observations from the Murrumbidgee catchment., Department of Civil and Environmental Engineering, The University of Melbourne, 2008.

Zreda, M., Desilets, D., Ferre, T. P. A., and Scott, R. L.: Measuring soil moisture content non-invasively at intermediate spatial scale using cosmic-ray neutrons, Geophys. Res. Lett., 35, L21402, 10.1029/2008gl035655, 2008.

Zribi, M., Pardé, M., De Rosnay, P., Baup, F., Boulain, N., Descroix, L., Pellarin, T., Mougin, E., Ottlé, C., and Decharme, B.: ERS scatterometer surface soil moisture analysis of two sites in the south and north of the Sahel region of West Africa, J. Hydrol., 375, 253-261, 2009. 